

\section{Sumário}

I. Crônicas do Direito Internacional ...............................................1

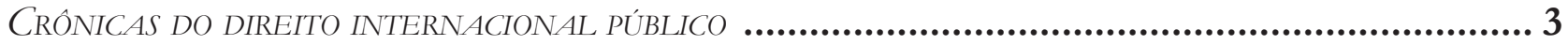

A resolução 2272 (2016) do Conselho de Segurança das Nações Unidas - O POSICIONAMENTO DA ONU FACE ÀS ALEGAÇÕES DE ABUSO E EXPLORAÇÃo SEXUAL POR SUAS

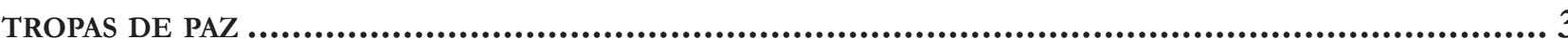

Sarah Dayanna Lacerda Martins Lima

CRÓNICAS DE DiREITo INTERNACIONAL PRIVADO...................................................................

Nadia de Araujo, Marcelo De Nardi, Gustavo Ribeiro, Fabrício Polido e Inez Lopes

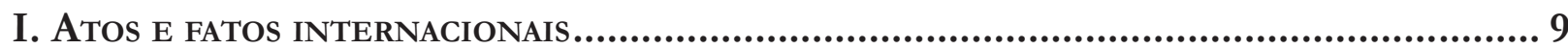

Crônica 1. Novidades de 2017 SObRE CIRCulaÇÃo faCilitada DE SENTENÇAS ESTRANGEIRAS 9

Crônica 2: O Direito Transnacional e os episódios das Carnes.........................................16

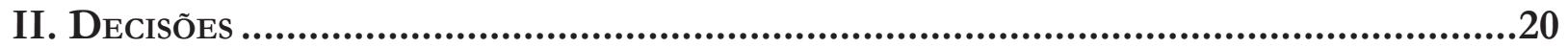

Crônica 3: A Irresistível ForÇa da ORDEM PÚblica E A HOMOLOGaÇÃo DE SENTENÇAS

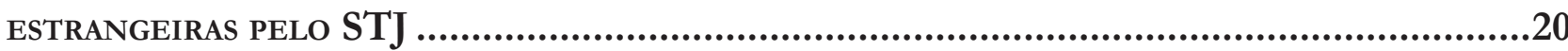

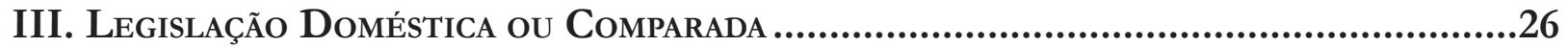

Crônica 4 - Dignidade da pessoa humana e mudança de paradigma da Lei de Migração

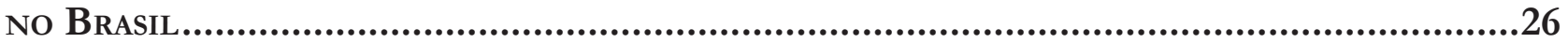

II. Dossiê especial: Direito Internacional dos InVEstimentos ................35

Non-adjudicatory State-State Mechanisms in Investment Dispute Prevention and Dispute Settlement: Joint Interpretations, Filters and Focal Points 
Mapping the Duties of Private Companies in International Investment Law .50 Nitish Monebhurrun

LA LÉGALITÉ DE L'INVESTISSEMENT DEVANT L'ARBITRE INTERNATIONAL: À LA RECHERCHE D'UN POINT D'ÉQUILIBRE .73 Hervé Ascensio

Host STATES AND STATE-STATE INVESTMENT ARBITRATION: STRATEGIES AND CHALlENGES......81 Murilo Otávio Lubamdo de Melo

Right to Regulate, Margin of Appreciation and Proportionality: Current Status in Investment Arbitration in Light of Philip Morris V. Uruguay. .95 Giovanni Zarra

Investments on Disputed Territory: Indispensable Parties and Indispensable Issues....122 Peter Tzeng

The Influence of General Exceptions on the Interpretation of National

Treatment in INTERNATIONAL INVESTMENT LAW. 140 Louis-Marie Chauvel

UMA PRoposta de REFleXão SObRe os ACFIs: Até QUE PONTO O TRATAMENTo de NAÇão MAIS FAVORECIDA PODE MINAR A ESTRATÉGIA POLÍTICA QUE OS EMBASA? 160

Michelle Ratton Sanchez Badin, Daniel Tavela Luis e Mario Alfredo de Oliveira

ECUADOR's 2017 TERMINATION OF TREATIES: HOW NOT TO EXIT THE INTERNATIONAL INVESTMENT REGIME 179

Jose Gustavo Prieto Muñoz

ONE BELT, ONE ROAD: NOVAS INTERFACES ENTRE O COMÉRCIO E OS INVESTIMENTOS INTERNACIONAIS 193

Flávio Marcelo Rodrigues Bruno e Marilda Rosado de Sá Ribeiro

III. Artigos Sobre outros TEMAS..................................................... 214

TolerânCIA E REFugIO: UM ENSAIO A PARTIR Do ACORdo EU-TurQUiA 216 Flávia Cristina Piovesan e Ana Carolina Lopes Olsen 
O TRATAMENTO do APÁtridA NA NOVA LEI DE MIGRAÇÃo: ENTRE AVANÇOS E RETROCESSOS...237 Jahyr-Philippe Bichara

O caráter humanista da Lei de Migrações: aVAnços da Lei N. 13.445/2017 E Os desafios DA REGULAMENTAÇÃO. 254 Marcelo Dias Varella, Clarice G. Oliveira, Mariana S.C. Oliveira e Adriana P. Ligiero

Reform of the United Nations Security Council: The Emperor Has No Clothes.268 Ljubo Runjic

A IDEIA DE QUe os LATINO-AMERICANOS PREFEREM O AUTORITARISMO À DEMOCRACIA À luz da reinterpretação dos Critérios do Programa das Nações Unidas para o DesenVolvimento 286

Gina Marcilio Pompeu e Ana Araújo Ximenes Teixeira

A PRoteção da ORIENTAÇÃo SEXUAL E IDENTIDAdE DE GÊNERO DIVERSAS NA CORTE PENAL internacional: Entre Realpolitiks E Os Direitos Humanos

Gustavo Bussmann Ferreira

A desnacionalização e as violações de direitos humanos na República Dominicana. 331 Daniela Menengoti Gonçalves Ribeiro e Rodrigo Ichikawa Claro Silva

CompetênCia do TPI no Caso do ATAque ao hospital de Kunduz: uma análise ENVOLVENDO A JURISDiÇÃo do TPI EM RELAÇÃO A NACIONAIS DE EsTAdOS NÃO-PARTE do Estatuto DE Roma

Filipe Augusto Silva e Renata Mantovani de Lima

A CRIMINALIZAÇÃo DOS IMIGRANTES EM SITUAÇÃo IRREGULAR NA ITÁliA: BIOPOLÍtica E DIREITO PENAL DO AUTOR.

Maiquel Angelo Dezordi Wermuth e Jeannine Tonetto de Aguiar

The New Rules On Trade And Environment Linkage In Preferential Trade Agreements

Alberto do Amaral Júnior e Alebe Linhares Mesquita

Beyond THE Border between the North and the South: towards a Decolonization of EPISTEMOLOGIES AND FIELDS OF RESEARCH ON MERCOSUR 
A aplicabilidade da Convenção de Montreal no direito brasileiro.

Aziz Tuffi Saliba e Alexandre Rodrigues de Souza

REgIME DE TRANSPARÊNCIA FISCAL NA TRIBUTAÇÃo DOS LUCROS AUFERIDOS NO EXTERIOR (CFC RULES): LACUNAS E CONFLITOS NO DIREITO BRASILEIRO

Paulo Rosenblatt e Rodrigo Torres Pimenta Cabral

As Regras Brasileiras de Tributação de Controladas e Coligadas no Exterior: verdadeiras Controlled Foreign Company (CFC) Rules? .......................................465

Melina de Souza Rocha Lukic e Amanda Almeida Muniz

O RETORNO DE BENS CULTURAIS

Aziz Saliba e Alice Lopes Fabris

Direitos culturais e Nações Unidas: uma análise a partir da Declaração Sobre a eliminação de Todas as Formas de Intolerância e Discriminação Baseadas na Religião OU NA CRENÇA

Leilane Serratine Grubba e Márcio Ricardo Staffen

OS REFLEXOS DA PROTEÇÃO INTERNACIONAL DA PROPRIEDADE INTELECTUAL PARA O DESENVOLVIMENTO INTERNO: UMA ANÁLISE SOBRE O SISTEMA PATENTÁRIO BRASILEIRO E A TRANSFERÊNCIA DE TECNOLOGIA

Michele M. Segala e Isabel Christine S. De Gregori

O CASO HIPOTÉTICO DA MORTE DO EMBAIXADOR FRANCÊS NA ESPANHA: DUAS ESPÉCIES DE IUS gentium em Francisco de Vitoria

Rafael Zelesco Barretto

De volta À BeVilaqua: anÁlise ECONÔMICA dA APLICAÇão do ART. $9^{\circ}$ DA LINDB Às OBRIGAÇÕES CIVIS CONTRATUAIS

Danielle Cristina Lanius e Ivo Teixeira Gico Jr 


\title{
The New Rules On Trade And Environment Linkage In Preferential Trade Agreements*
}

\author{
As Novas Regras sobre a Relação entre \\ Comércio e Meio Ambiente em Acordos \\ Preferenciais de Comércio
}

\author{
Alberto do Amaral Júnior** \\ Alebe Linhares Mesquita***
}

\section{Abstract}

The present paper aims to analyze the advancement of environmental provisions in Preferential Trade Agreements (PTAs), more specifically, in the Trans-Pacific Partnership (TPP). Even though the TPP might never enter into force due to political changes in the United States' government, the rules established under it represent the new benchmark on trade and environment linkage. The language adopted in the Agreement is already guiding negotiations in the multilateral, plurilateral and bilateral level. This study is divided into three main sections. In the first section, the interplay between international trade and protection of the environment will be depicted. In the second section, the phenomenon of the advancement of environmental provisions in PTAs will be analyzed. In the third section, the environmental provisions consolidated in the TPP will be considered. The methodology adopted in the development of this research is bibliography, descriptive and exploratory. In conclusion, it can be asserted that incorporation of environmental provisions in PTAs has assumed an increasing importance in the efforts to render international trade and environmental protection mutually supportive and to achieve sustainable development goals. Among PTAs, the TPP stands out as the most modern advanced in terms of environmental provisions. However, the TPP's analysis demonstrated that environmental consequences of the implementation of preferential trade agreements should be further assessed. This would allow the elaboration of preventive measures to overcome possible side effects, such as the increase of trade in fossil fuels or the reallocation of pollution intensive industries, due to the other trade liberalization provisions.

Keywords: Environment. Preferential Trade Agreements. TPP.

** Associate Professor for International Law of the Faculty of Law at University of São Paulo (USP), since 2001, and visiting scholar at Yale Law School, in 2003 and 2007. E-mail: aamaralj@uol.com.br

*** Lawyer enrolled in the Master Program of International and Comparative Law at University of São Paulo (USP) working currently at the Swiss Federal Institute of Intellectual Property (IPI). Fellow with the SYLFF/Tokyo Foundation Program. E-mail: alebe_linhares@ hotmail.com

\section{Resumo}

O presente artigo pretende analisar a expansão de dispositivos ambientais em Acordos Preferenciais de Comércio (APCs), mais especificamente, no Acordo Transpacífico (TPP). Mesmo que o TPP nunca chegue a entrar em vigor devida a mudanças políticas no governo dos Estados Unidos, a regras nele estabelecidas representam a nova referência sobre a relação en- 
tre comércio e meio ambiente. A linguagem adotada no Acordo já orienta as negociações em níveis multilateral, plurilateral e bilateral. Este estudo é dividido em três seções principais. Na primeira, a interação entre comércio internacional e meio ambiente será demonstrada. $\mathrm{Na}$ segunda, o fenômeno da expansão dos dispositivos ambientais nos APCs será analisado. Na terceira, os dispositivos ambientais consolidados no TPP e a as suas implicações serão considerados. A metodologia adotada no desenvolvimento desta pesquisa é bibliográfica, descritiva e exploratória. Em conclusão, pode-se afirmar que a incorporação de normas ambientais em APCs vem assumindo uma importância crescente nos esforços para tornar o comércio internacional e a proteção ambiental mutualmente favoráveis e para se alcançar as metas do desenvolvimento sustentável. Dentre os APCs, o TPP se destaca como o mais moderno e avançado em termos de dispositivos ambientais. No entanto, a análise do TPP demonstrou que as consequências ambientais da implementação de acordos preferenciais de comércio devem ser avaliadas mais profundamente. Isso permitira a elaboração de medidas preventivas para superar possíveis efeitos colaterais, como o aumento do comércio de combustíveis fósseis ou a realocação de indústrias de poluição intensiva, decorrentes de outros dispositivos de liberação comercial.

Palavras-Chave: Meio Ambiente. Acordos Preferenciais de Comércio. TPP.

\section{INTRODUCTION}

It is no longer reasonable to envisage a sustainable economic order disconnected from an international trading system that promotes environmental protection. Since the end of the twentieth century, environmental protection has acquired an unprecedented importance thanks to huge risks coming from the stunning degradation of nature. As an outcome, the relationship between international trade and the environment sets the center stage so as to alleviate awful menaces that hover on the entire Humanity.

At the multilateral level, the World Trade Organization (WTO) progress on this matter has been modest. The exception clause of the General Agreement on Tariffs and Trade (GATT) lists situations and requirements that allow countries to disregard the liberaliza- tion duties accorded. Article XX $b$ and $g$ determines, respectively, that nothing in the Agreement shall be construed to prevent the adoption or enforcement by any contracting Party of measures necessary to protect human, animal or plant life or health; and relating to the conservation of exhaustible natural resources. ${ }^{1}$ This article inspired similar provisions included in other WTO Agreements.

The Agreements on Technical Barriers to Trade (TBT Agreement) and on the Application of Sanitary and Phytosanitary Measures (SPS Agreement) are particularly important because they authorize trade restrictions so that legitimate environmental objectives can be achieved. Under the TBT Agreement, technical regulations shall not be more trade-restrictive than necessary to fulfill a legitimate goal, such as the protection of human health or safety or plant life or health, or the environment (Article 2.2). Under the SPS Agreement, sanitary and phytosanitary measures shall be applied based on scientific principles and only to the extent to protect human, animal or plant life or health (Article 2.2). The SPS Agreement also covers ecological and environmental criteria within its conditions for risk assessment (Article 5.2) and demands governments to take into consideration ecosystems as one aspect in determining disease or pest free areas (Article 6.2).

The Agreement on Trade-Related Aspects of Intellectual Property Rights (TRIPS Agreement) also alludes to the environmental protection by establishing an exception with respect to patents. Members may exclude an invention from patentability when necessary to protect human, animal or plant life or health or to avoid serious prejudice to the environment (Article 27.2).

1 It is also worth mentioning that in the EC - Seals Products Case (DS401) the exception of the article XX (a) was recognized as potentially usable for assuring animal-welfare. The Appellate Body upheld the Panel's decision that the EU Seal Regime is 'necessary to protect public morals' within the meaning of Article XX (a) of the GATT 1994 (Appellate Body Report, European Communities - Measures Probibiting the Importation and Marketing of Seal Products, WTO Doc WT/DS401/AB/R (22 May 2014)). In the India - Solar Cells Case (DS456), India has also try to justify its domestic content requirements in the initial phase of the national solar mission under the exceptions of Article XX (d) and (j). However, India's attempt was unsuccessful and the Panel found that it failed to demonstrate application of such exceptions. On April 2016, India notified the Dispute Settlement Body of its decision to appeal to the Appellate Body certain issues of law and legal interpretation in the panel report (Panel Report, India - Certain Measures Relating to Solar Cells and Solar Modules, WTO Doc WT/DS456/R (24 February 2016)). 
The Doha Round impasse precluded the advancement of important trade related environmental rules. Presently, there is no specific WTO Agreement that deals directly with the promotion of sustainable development through trade liberalization. This subject is approached separately in different provisions of the WTO multilateral agreements.

The most significant initiative on the environmental mandate brought by the Doha Development Agenda is found in the negotiation of the Environmental Goods Agreement (EGA). ${ }^{2}$ So far, the goods object of negotiation cover a broad range of environmental categories, like air pollution control, renewable energy, waste management and wastewater treatment. Even so, EGA's talks are far from being concluded.

Preferential trade agreements (PTAs) have disseminated too fast since the end of the Uruguay Round. A vast amount of PTAs either increases the scope of the WTO rules or regulate subject matters that do not belong to the multilateral trading system. Their negotiations have yielded effects not yet fully assessed.

Translating pressures from civil societies, preferential trade agreements came to contain environmental clauses or even entire chapters on that matter. Rules vary in accordance with the specificity, legal depth and bindingness of the commitments. They do not only reaffirm what has been adopted under the WTO Agreements, but also advance on topics not yet regulated by the Organization, exemplified by fisheries subsidies, illegal logging and wildlife trafficking.

Among the new generation of PTAs, special attention should be drawn to negotiation of the Mega Regional Trade Agreements (Mega-RTAs), a label coined to mean agreements bringing together the most powerful world economies. Due to their geographic extension and economic relevance, the topics that are being currently negotiated or have already been adopted will certainly be multilateralized in the future.

The Trans-Pacific Partnership (TPP) connects ele-

2 The 17 participants in the negotiation of the Environmental Goods Agreement are: Australia, China, Costa Rica, the European Union (representing 28 members); Hong Kong, China; Iceland; Israel; Japan; Korea; New Zealand; Norway; Singapore; Switzerland; Separate Customs Territory of Taiwan; Penghu; Kinmen and Matsu; Turkey; and the United States (WTO SECRETARIAT. Trade and Enviroment: DG Azevedo welcomes progress in Environmental Goods Agreement. Available at: <https://www.wto.org/english/news_e/ news15_e/envir_14dec15_e.htm>. Accessed on: 16 Dec. 2016). ven economies of Asia and the Pacific Ocean to the US economy. Originally a Free Trade Agreement between Brunei, Chile, New Zealand and Singapore (Pacific-4), the TPP comprises more eight countries: United States, Australia, Canada, Japan, Malaysia, Mexico, Peru and Vietnam. It amounts to $36.3 \%$ of the world GDP and $25.5 \%$ of the world trade. After five years of negotiations, the countries achieved a final version of the Agreement in October 2015 in Atlanta (United States). The TPP has been the deepest plurilateral trade agreement signed since the end of the Uruguay Round in 1994. To enter into force, it is necessary the approval by the legislative powers of all signatory countries within a period of two years since the Agreement's signature or - after the expiry of this period - by at least 6 countries, which together account for at least $85 \%$ of the combined GDP of the original signatories. ${ }^{3}$

Given the political changes in the United States' government due to the election of Donald Trump for president, it is unlikely that the agreement might one day produce its legal effects. In his first week as president of the United States, Donald Trump withdrew the U.S from the TPP, keeping with one of its campaign promises. During Barack Obama's administration, the TPP was never presented to the U.S Congress given the lack of necessary parliamentary support to adopt the agreement. Even though the TPP might never enter into force, the rules established under it represent the new benchmark for trade and environment linkage and are already guiding negotiations on this matter in the multilateral, plurilateral and bilateral level. Its importance resides in the language consensus achieved by 12 developed and developing on a controversial topic. The TPP text will shed light in the future international negotiations and norm-setting. Therefore, it is so relevant to assess its provisions and implications for the governance of international trade and environment.

From this perspective, this article intends to analyze

3 THORSTENSEN, Vera; NOGUEIRA, Thiago; ARIMA JÚNIOR, Mauro. Introdução. In: THORSTENSEN, Vera; NOGUEIRA (Coord.). O Tratado da Parceria Transpacifica (TPP): Impactos do Novo Marco Regulatório para o Brasil. São Paulo: VT, 2017. p. 47. In this regard, Thorstensen et al. highlight that the $85 \%$ 's figure was not a random choice. The TPP could not enter into force if it were not ratified jointly by the two largest economies of the trading bloc: United States and Japan. These countries, respectively, amount for $63 \%$ and $17 \%$ of the combined GDP of the original signatories. Hence, the United States and Japan, even separately, could prevent the entry into force of the TPP. 
the evolution of the relationship between trade and environment beyond the WTO, in PTAs, paying particular attention to the TPP. We are specifically concerned with a particular question of whether a balanced relationship was achieved between trade and the environment. This paper is divided into three main sections.

In the first section, the interplay between international trade and the environmental protection will be depicted. The aim is to demonstrate the environmental effects for international trade, especially how and to what extent the liberalization and the expansion of international trade can harm or help the protection of the environment.

In the second section, the inclusion of environmental provisions in Preferential Trade Agreements will be considered. Our purpose is to investigate the types of environmental provisions adopted, the ways in which they have been incorporated and the main incentives for embracing those clauses.

At last, the provisions adopted under the Environment Chapter (Chapter 20) of the Trans-Pacific Partnership will be assessed. The TPP represents the most advanced regulatory framework in terms of trade and environment linkage.

The importance of this research resides in identifying the main trends and patterns concerning the adoption of environmental provisions in the TPP. This is crucial to understand the relationship between regionalism and multilateralism and to foresee its consequences for the international trade regulation.

\section{International Trade And The Protection Of The Environment}

The first major initiative to incorporate environmental provision into the world trading system dates back to Uruguay Round (1986-1994), curiously the same period that the Rio Summit on the Environment and Development took place. Naturally, some conclusions of that summit reverberated in the Uruguay Round. More broadly, international environmental law started actually to be consolidated in 1960s.

Nevertheless, drawing on the observation by Dupuy and Viñuales, the failed Havana Charter ${ }^{4}$ and even its predecessor, 'the 1927 Convention for the Abolition of Import and Export Prohibitions and Restrictions, ${ }^{5}$ both contained explicit exceptions to accommodate what today would be called environmental measures. ${ }^{6}$ The 1947 GATT only incidentally alluded to protection of natural resources. ${ }^{7}$

Throughout time, international trade and the environmental protection have followed different paths, rarely crossing their sphere. Both fields had different logics and principles to address particular problems. However, due to the swift depletion of natural resources deriving from the industrialization process, the environmental protection became a political sensitive issue mobilizing both societies and governments to enhance the interaction between trade and the environment. ${ }^{8}$

The grass roots social movements played a decisive role in the formulation of claims for environmental regulation. NGOs acted in several fronts, such as information collection and dissemination, policy development consultation, policy implementation, assessment and monitoring and advocacy for environmental justice. ${ }^{9}$ Its political activism grew continuously and its influences could be noticed in the outcomes of 1972 and 1992 United Nations Conferences. ${ }^{10}$

As new ecologically responsible standards were being internationally agreed, domestic environmental regulations have started to collide with trade obligations, reaching the GATT/WTO dispute settlement system. The multilateral trading dispute settlement system has already appreciated a number of trade disputes

4 Article 45 (1) (a) (x) of the Havana Charter for an International Trade Organization, 24 March 1948.

5 Article 4 of the Convention for the Abolition of Import and Export Prohibitions and Restrictions, 8 November 1927.

6 DUPUY, Pierre-Marie; VIÑUALES, Jorge. International Environmental Law. Cambridge: Cambridge University Press, 2015. p. 391.

7 LOWENFELD, Andreas. International Economic Law. 2. ed. Oxford: Oxford University Press, 2011. p. 372.

8 AMARAL JÚNIOR, Alberto. Comércio Internacional e Proteção do Meio Ambiente. São Paulo: Atlas, 2011. p. 139.

9 GEMMILL, Barbara; BAMIDELE-IZU, Abimbola. The role of NGOs and Civil Society in Global Environmental Governance. In: ESTY, Daniel C; IVANNOVA, Maria H. (Ed.). Global environmental governance: Options and opportunities. New Haven: Yale School of Forestry \& Environmental Studies, 2002. p. 77-78.

10 Article 12 of the 1992 Rio Declaration affirms that: 'trade policy measures for environmental purposes should not constitute a means for arbitrary or unjustifiable discrimination or disguised restriction on international trade.' 
involving environmental aspects, ${ }^{11}$ such as the notorious cases: US - Shrimp-Turtle; US - Tuna-Dolphin I and II; and Brazil - Retreated Tires. In order to illustrate this collision, it is worth highlighting briefly the most important aspects of these cases.

In the US - Shrimp-Turtle, India, Malaysia, Pakistan and Thailand claimed that the US regulation' ${ }^{12}$ 'requiring that all shrimpers, foreign and domestic, exporting shrimp to the USA use a 'turtle excluder device' (TED) according to the US agency standards ${ }^{13}$ violated GATT's Articles XI (prohibition on quantitative restrictions). The United States alleged that this measure fell under the GATT Article XX (general exceptions) $b$ (animal life) and $g$ (exhaustible natural resources). The US supported that this measure was necessary to avoid the accidental catch of sea turtles and other endangered species both under the Convention on International Trade in Endangered Species of Wild Fauna and Flora (CITES) and the 1973 US Endangered Species Act. ${ }^{14}$

The United States appealed the panel's ruling, which found the US measure to be in violation of Article $\mathrm{XI}$ and not justifiable under Article XX. ${ }^{15}$ The Appellate Body recognized that 'under W'TO rules, countries have the right to take trade action to protect the environment (in particular, animal or plant life and health) and endangered species and exhaustible resources). ${ }^{36}$ However, the Appellate Body kept the panel's ruling on Article XX, because the US measure discriminated unjustifiably between WTO Members. It provided other countries - mainly in the Caribbean - more favorable conditions regarding the use of TEDs than the four

11 Examples of trade-related environmental disputes include: United States - Taxes on Automobiles; United States - Standards for Reformulated and Conventions Gasoline; European Communities - Trade Description of Sardines; and European Communities - Measures Affecting the Approval and Marketing of Biotech Products.

12 Section 609 of the Public Law 101-162.

13 TRUJILLO, Elizabeth. A Dialogical Approach to Trade and Environment. Journal of International Economic Law, Oxford, v. 16, n. 3, p. 548, Mar. 2013.

14 TRUJILLO, Elizabeth. A Dialogical Approach to Trade and Environment. Journal of International Economic Law, Oxford, v. 16, n. 3, p. 548, Mar. 2013.

15 For a deeper analysis of the case see: HOWSE, Robert. The Appellate Body Ruling in the Shrimp/Turtle Case: A New Legal Base Line for the Trade and Environment Debate. Columbia Journal of International Law, v. 27, n. 2, p. 491-521, 2002.

16 WORLD TRADE ORGANIZATION. India etc versus US: Shrimp-Turtle. Available at: <https://www.wto.org/english/ tratop_e/envir_e/edis08_e.htm>. Accessed on: 18 Jul. 2017.
Asian countries (India, Malaysia, Pakistan and Thailand) that failed the complaint. ${ }^{17}$

In the United States - Tuna-Dolphin I, Mexico complaint that the "US moratorium on imports of Mexican yellowfin tuna through the implementation of US Marina Mammal Protection Act [MMPA]"18 violated GATT's Articles III (national treatment), XI (prohibition on quantitative restrictions) and XIII (non-discriminatory administration of quantitative restrictions). The USA refuted the applicability of the mentioned GATT provisions and argued that its measure was allowed under GATT XX $b$ and $g$. The MMPA aimed to promote the preservation of dolphins found in the tropical east of the Pacific Ocean through reducing their death caused by tuna fishing with the use of purse seine nets. ${ }^{19}$

The panel conclusions can be summed up in two main rulings. First, 'the US could not embargo imports of tuna products from Mexico simply because Mexican regulations on the way tuna was produced did not satisfy US regulations' ('product' versus 'process'). ${ }^{20}$ Considering that the measure "related to the process of capturing tuna and not the final product itself, [...] GATT Article III was not applicable." 21 Second, the 'GAT'T rules did not allow one country to take trade action for the purpose of attempting to enforce its own domestic laws in another countryy ${ }^{22}$ (extraterritoriality). ${ }^{23}$ The panel found that 'the US moratorium was beyond the reach of US jurisdiction and, therefore, did not qualify

17 WORLD TRADE ORGANIZATION. India etc versus US: Shrimp-Turtle. Available at: <https://www.wto.org/english/ tratop_e/envir_e/edis08_e.htm>. Accessed on: 18 Jul. 2017.

18 TRUJILLO, Elizabeth. A Dialogical Approach to Trade and Environment. Journal of International Economic Law, Oxford, v. 16, n. 3, p. 535-585, mar. 2013, p. 545.

19 AMARAL JÚNIOR, Alberto. Comércio Internacional e Proteção do Meio Ambiente. São Paulo: Atlas, 2011. p. 220.

20 WORLD TRADE ORGANIZATION. Mexico etc versus US: Tuna-Dolphin. Available at: <https://www.wto.org/english/ tratop_e/envir_e/edis04_e.htm>. Accessed on: 19 Jul. 2017.

21 TRUJILLO, Elizabeth. A Dialogical Approach to Trade and Environment. Journal of International Economic Law, Oxford, v. 16, n. 3, p. 535-585, mar. 2013, p. 546.

22 WORLD TRADE ORGANIZATION. Mexico etc versus US: Tuna-Dolphin. Available at: <https://www.wto.org/english/ tratop_e/envir_e/edis04_e.htm>. Accessed on: 19 Jul. 2017.

23 It is worth noting that the panel's report was never adopted. Mexico decided to pursue bilateral consultations with the USA in order to achieve an agreement outside GATT (WORLD TRADE ORGANIZATION. Mexico etc versus US: Tuna-Dolphin. Available at: <https://www.wto.org/english/tratop_e/envir_e/edis04_e. htm>. Accessed on: 19 Jul. 2017). 
for any of the GATT Article XX exceptions. ${ }^{24}$

In the US - Tuna-Dolphin II, the European Community and the Netherlands brought a similar complaint questioning the US Marina Mammal Protection Act. The panel resumed the previously defended theses in US - Tuna-Dolphin $\mathrm{I}^{25}$ This ruling differs from the previous by finding that 'regulatory measures for the protection of human, animal, or plant life could be valid under Article XX (b) even if these measures were not confined to the jurisdictional boundaries of the state implementing the regulation. ${ }^{26}$ The panel, however, did not give further guidance as to under what circumstances. $^{27}$

In the Brazil - Retreaded Tires, the EU claimed that the Brazilian ban and penalties on retreated tires imports from non-MERCOSUR countries ${ }^{28}$ consisted a violation of GATT Articles I (most-favored-nation treatment), III (national treatment), XI (prohibition on quantitative restrictions) and XIII (non-discriminatory administration of quantitative restrictions). ${ }^{29}$ This Brazilian ban was in accordance with the MERCOSUR's Arbitral Award No. 01/2006, exempting MERCOSUR countries from this measure. Brazil argued that its measures intended to reduce the harms produced by retreaded tires in the country, because their undue disposal and toxic composition could pose risks to human, animal and plant life and health. Besides, abandoned retreated tires still a serious public health problem in the country, since they are the birthplace of the aedes aegrpti mosquito, the vector of several infectious diseases such as dengue. ${ }^{30}$ Brazil alleged that its measures were justi-

24 TRUJILLO, Elizabeth. A Dialogical Approach to Trade and Environment. Journal of International Economic Law, Oxford, v. 16, n. 3, p. 546, Mar. 2013.

25 AMARAL JÚNIOR, Alberto. Comércio Internacional e Proteção do Meio Ambiente. São Paulo: Atlas, 2011. p. 221.

26 TRUJILLO, Elizabeth. A Dialogical Approach to Trade and Environment. Journal of International Economic Law, Oxford, v. 16, n. 3, p. 547, Mar. 2013.

27 TRUJILLO, Elizabeth. A Dialogical Approach to Trade and Environment. Journal of International Economic Law, Oxford, v. 16, n. 3, p. 547, Mar. 2013.

28 Brazilian National Environment Council (CONAMA)'s Resolution No. 258/99.

29 TRUJILLO, Elizabeth. A Dialogical Approach to Trade and Environment. Journal of International Economic Law, Oxford, v. 16, n. 3, p. 571, Mar. 2013.

30 MATIAS, João Luis Nogueira; ZANOCCHI, José Maria McCall. A Compatibilização entre o Comércio Internacional e a Proteção do Meio Ambiente no Âmbito da OMC: Análise do Caso das Restrições à Importação de Pneus Recauchutados pelo Brasil. Anais do XX Encontro Nacional do CONPEDI, Florianópolis: Fundação fied under GATT Article XX $b$.

The EU appealed the panel's ruling to the Appellate Body, which, in general terms: (i) maintained the panel's finding that the import ban can be considered 'necessary' within the meaning of Article XX $b ;{ }^{31}$ but (ii) it decided that the measure was not the least restrictive means of pursuing the environmental objective, being applied in a arbitrary manner, leading to unjustifiable discrimination in regard to non-MERCOSUR. ${ }^{32}$

The above-mentioned cases are just a few examples of intricate interface between trade and environment protection. Today we are confronted with a huge environmental crisis that prevents the nature from recovering. Further, this rationale interferers with the fragile environmental balance of the planet. The unbridled international trade tends to boost an ever-greater degradation of natural resources, pushing the planet to its limits.

Trade issues are linked to central environmental challenges, such as: climate change; unsustainable use of natural resources; biodiversity losses; the air, land and ocean pollution; and desertification. They put not only the environment at risk, but also human health and livelihoods around the globe. ${ }^{33}$ By accelerating the level of economic activity, they provoke the exaggerated use of the earth's resources, far beyond the natural replacement rate, and the use of non-renewable resources in an incompatible manner with the basic principles of sustainability. International trade has the potential to become a powerful source of environmental degradation if environmental values are not taken into consideration. ${ }^{34}$

It is worth noting that regulatory requirements for the sustainable management of natural resources, environmental impact assessment studies, treatment of

Boiteux, p. 4994-5016, 2011.

31 WORLD TRADE ORGANIZATION. Brazil: Measures Affecting Imports of Retreaded Tyres. Available at: <https://www. wto.org/english/tratop_e/dispu_e/cases_e/ds332_e.htm>. Accessed on: 19 Jul. 2017.

32 TRUJILLO, Elizabeth. A Dialogical Approach to Trade and Environment. Journal of International Economic Law, Oxford, v. 16, n. 3, p. 572, Mar. 2013.

33 BIRKBECK, Carolyn Deere; BOTWRIGHT, Kimberley. The Future of the Global Trade and Investment Architecture: Pursuing Sustainable Development in the Global Economy - Overview of Issues, Challenges and Debates. Geneva: International Centre for Trade and Sustainable Development and World Economic Forum, 2015. p. 33.

34 AMARAL JÚNIOR, Alberto. Comércio Internacional e Proteção do Meio Ambiente. São Paulo: Atlas, 2011. p. 143-144. 
industrial waste as well as the reparation and compensation in case of environmental damage are not yet a consensus at international level. As a result, a country that has stricter environmental rules is in a less favorable position in commercial terms than the one that has more flexible rules. This stems from the fact that the value of the goods produced in its territory does not reflect the costs related to the compliance with minimum standards of environmental protection, rendering them more competitive in the global market.

This situation demonstrates a negative effect of trade liberalization. Highly polluting and/or extensive natural resource-based enterprises are encouraged to move to countries whose legislation and environmental requirements are softer. Enterprises mostly located in the European Union and in the United States try to move to pollution havens, in order to escape from its stringent national environmental law and, consequently, higher production costs.

In this respect, Frankel asserts that: 'openness to trade might encourage some countries to specialize in dirtier activities, and export their products to others with higher environmental standards. ${ }^{35}$ On this view, international trade liberalization has its primary effect on the distribution of pollution across countries, rather than on the overall average. ${ }^{36}$

In addition, countries with low environmental protection rules are not motivated to adopt more severe environmental rules and those that already have stricter rules find themselves tempted to lower their level of environmental protection to attract new foreign investments. ${ }^{37}$ This represents the well-known race-to-the bottom hypothesis. Open countries in general adopt less stringent environmental regulations than less open countries out of fear of adverse effects on their international competitiveness. ${ }^{38}$ Countries are led to maintain the lowest level of environmental protection as much as possible to keep their competitiveness in the global market. However, the race-to-the-bottom argument is

35 FRANKEL, Jeffrey. Environmental Effects of International Trade. Västerås: Sweden’s Globalisation Council, 2009. p. 7.

36 FRANKEL, Jeffrey. Environmental Effects of International Trade. Västerås: Sweden's Globalisation Council, 2009. p. 9.

37 QUEIROZ, Fábio Albergaria. Meio ambiente e comércio internacional: relação sustentável ou opostos inconciliáveis? Argumentos ambientalistas e pró-comércio do debate. Contexto Internacional, Rio de Janeiro, v. 31, n. 2, p. 258-259, maio/ago. 2009.

38 FRANKEL, Jeffrey. Environmental Effects of International Trade. Västerås: Sweden's Globalisation Council, 2009. p. 7. questioned by empirical accuracy, as countries might have other genuinely environmental concerns that point in the opposite direction. China, for example, wants to reduce air pollution at all costs.

Moreover, arguments advocating potential benefits between the two fields must be remarked. The expansion of international trade, some authors opine, could favor technical innovation and, consequently, the dissemination of less polluting forms of production. Open markets are used to stimulate the empowerment of consumers who could spur the adoption of sustainable corporate codes of conduct. Besides, the so-called Environmental Kuznets Curve ${ }^{39}$ shows that even tough at early stages of economic development growth may bring a deterioration in the environment, after a particular critical level is reached, the further growth brings an improvement. ${ }^{40}$ Hence, the trade effects on the environment would be beneficial in the long run.

As it stands, the impact of trade liberalization on environmental protection is ambiguous. As noted by Professors Dupuy and Viñuales, this interaction may place constraints on legitimate environmental restrictions or contribute to the wider circulation of polluting substances, but it may also lead to a more efficient use of natural resources, as a result of global competition among producers, or to a wider circulation of environment-friendly goods and technologies. ${ }^{41}$

As can be observed, no matter the assumption about the relation between the two fields, one thing is sure: there is an inseparable link between international trade and environmental protection in the pursuit of sustainable development. According to studies developed by the Organization for Economic Cooperation and Development (OECD), environmental problems are not caused by trade itself, but by market and intervention failures that occur, respectively, when markets do not reflect the environmental values and public policies create, aggravate or do not correct those failures. ${ }^{42}$

39 The environmental Kuznets Curve is a loose U-shaped relationship between income and environmental quality (FRANKEL, Jeffrey. Environmental Effects of International Trade. Västerås: Sweden's Globalisation Council, 2009. p. 6).

40 FRANKEL, Jeffrey. Environmental Effects of International Trade. Västerås: Sweden's Globalisation Council, 2009. p. 6.

41 DUPUY, Pierre-Marie; VIÑUALES, Jorge. International Environmental Law. Cambridge: Cambridge University Press, 2015. p. 391. 42 ORGANIZATION FOR ECONOMIC COOPERATION AND DEVELOPMENT. The Environmental Effects of Trade. Paris: OECD Publications, 1994. p. 8. 
Among market failures, special attention should be given to externalities. They occur when the actions of one person affect others who do not receive any compensation by the damage caused or by the benefits created. ${ }^{43}$ Negative externalities happen when the action of one party imposes costs on others, for example, the emission of polluting gases. Positive externalities take place when the action of one party is beneficial to others, such as the conservation of tropical forests. ${ }^{44}$ As externalities are not turned out in the price, they end up becoming a cause of economic inefficiency. Its incorporation into the market is extremely important to adjust economic rules to environmental protection.

In this sense, the costs of negative externalities lie in the option of getting rid of the waste of a particular production process without treatment, leaving this burden to the nature. Instead of being embedded in the final price, the cost of pollution is transferred to the environment, inhabitants, fauna and flora. Economic agents wish to privatize profits and socialize losses and production costs. ${ }^{45}$

Therefore, the current dynamic of international trade should be modified to internalize damages to the environment. The contemporary challenges require joint initiatives to incorporate environmental provisions into the international trading system structure, so that minimum environmental standards form part of its normative framework. Environment and trade policies ought to be mutually supportive.

Trade should not be understood as an end in itself, but as a tool to achieve the noblest human purposes, which were to Montesquieu and Kant peace and harmony among men. ${ }^{46}$ Countries must reassess ways in which international trade can be successfully used to foster the protection of the environment as opposed to its degradation. ${ }^{47}$

A major step in this direction has come about under

43 AMARAL JÚNIOR, Alberto. Comércio Internacional e Proteção do Meio Ambiente. São Paulo: Atlas, 2011. p. 42.

44 PINDYCK, Robert; RUBINFELD, Daniel. Microeconomia. São Paulo: Makron Books, 1994.

45 CAUBET, Christian Guy. A Irresistível Ascensão do Comércio Internacional: o meio ambiente fora da lei? Revista de direito Ambiental, São Paulo, v.6, p. 92, abr./jun. 2001.

46 AMARAL JÚNIOR, Alberto. Comércio Internacional e Proteção do Meio Ambiente. São Paulo: Atlas, 2011. p. 127.

47 FRANKEL, Jeffrey. Environmental Effects of International Trade. Västerås: Sweden's Globalisation Council, 2009. p. 6. preferential trade agreements. Their regulatory expansion is building new pathways between trade and the environment. There are not only clauses on environmental protection but also entire chapters on the subject. Hence, it is valuable to analyze in what direction the international environmental trade rules are heading by investigating this new dynamic of trade negotiations.

\section{The Expansion Of EnVironmental Provisions In Preferential Trade Agreements}

In the last decades, the world witnessed the increasing proliferation of Preferential Trade Agreements (PTAs) ${ }^{48}$ concluded in parallel to the W'TO system. According to the 2013 World Trade Report, the number of agreements more than tripled between 1990 and 2010, from around 70 at the beginning of the period to nearly 300 at the end. ${ }^{49}$ As of $1^{\text {st }}$ July 2016, 635 of them have already been reported to the WTO, of which 423 are now in force. ${ }^{50}$ These numbers represents a shift in how trade is being regulated and negotiated internationally.

In accordance with Baccini and Dür, this phenomenon could be explained as a result of 'the stagnation of the process of multilateral trade liberalization, the search for economies of scale, the desire to signal commitment to specific trade and economic policies and the protection of foreign direct investments. ${ }^{51}$ In a similar vein, Baldwin understands this new wave of agreements as a response to the demands of the $21^{\text {st }}$ century regionalism that has as its core the trade-investment-service

48 Usually, researchers and policy-makers have adopted the terms Preferential Trade Agreements (PTAs) and Regional Trade Agreements (RTAs) more or less interchangeably due to the fact that PTAs traditionally have a strong regional orientation (WTO SECRETARIAT. 2013 World Trade Report. p. 75. Available at: <https:// www.wto.org/english/res_e/booksp_e/world_trade_report13_e. pdf $>$. Accessed on: 30 Nov. 2016). For now on, the present paper adopts the term PTA to describe this type of agreement.

49 WTO SECRETARIAT. 2013 World Trade Report. Available at: <https://www.wto.org/english/res_e/booksp_e/world_trade_ report13_e.pdf $>$. Accessed on: 30 Nov. 2016.

50 WTO SECRETARIAT. Regional Trade Agreements. Available at: <https://www.wto.org/english/tratop_e/region_e/region_e. htm>. Accessed on: 15 Nov. 2016.

51 BACCINI, Leonardo; DÜR, Andreas. The New Regionalism and Policy Interdependence. British Journal of Political Science, Cambridge, v. 42, n. 1, p. 57, jun. 2011. 
nexus. ${ }^{52}$

Although apparently incompatible with the central idea of the multilateral trading system, the Preferential Trade Agreements are not prohibited under the WTO Law. On the contrary, GATT's article XXIV allows its formation, as long as three conditions are met: (i) the customs duties and other regulations of commerce shall not be higher or more restrictive than before in the constituent territories; (ii) or in respect to third countries; and (iii) their reduction shall be scheduled within a reasonable period of time. ${ }^{53}$

Nevertheless, it is important to stress that this provision is a clear exception of the Most-Favored-Nation clause established under GATT's Article I. ${ }^{54}$ This waiver was allowed to enable countries to negotiate and reduce tariffs in smaller groups, making global trade liberalization easier.

However, increasingly PTAs go beyond the simple dismantling of border barriers to trade in goods. ${ }^{55}$ Those agreements now regulate services and other elements of integration, such as, regulatory liberalization, competition policy, investment and intellectual property protection. Moreover, traditionally PTAs were only restricted to tariff reduction, encompassing solely the already accepted WTO rules (WTO-in). ${ }^{56}$ PTAs have incorporated rules deepening the already existing regulation (WTO-plus) as well as rules about themes that don't pertain to the multilateral trading system (WTO-extra).

52 BALDWIN, Richard. $21^{\text {st }}$ Century Regionalism: filling the gap between $21^{\text {st }}$ century trade and $20^{\text {th }}$ century trade rules. WTO Staff Working Paper ERSD-2011-08. Available at: <https://www.wto. org/english/res_e/reser_e/ersd201108_e.pdf>. Accessed on: 16 Nov. 2016.

53 As stated under paragraph 5, (a) (b) (c), of 1994 GATT Article XXIV.

54 GATT's article I defines the Most-Favored-Nation Treatment as 'any advantage, favor, privilege or immunity granted by any contracting party to any product originating in or destined for any other country shall be accorded immediately and unconditionally to the like product originating in or destined for the territories of all other contracting parties.'

55 ROLLO, Jim. The Challenge of Negotiating RTAs for Developing Countries: what could the WTO do to help? In: BALDWIN, Richard; LOW, Patrick (Ed.). Multilateralizing Regionalism: Challenges for the Global Trading System. Cambridge: Cambridge University Press, 2009.

56 THORSTENSEN, Vera; FERRAZ, Lucas. A multiplicação dos acordos preferenciais de comércio e o isolamento do Brasil. São Paulo: Instituto de Estudos para o Desenvolvimento Industrial, 2013. Available at: $<$ http://retaguarda.iedi.org.br/midias/artigos/51d18e9168afa9d0. pdf $>$. Accessed on: 20 Dec. 2016.
In general terms, there is a trend of legal strengthening in all regulated areas. As observed by Badin and Tasquetto, this encompasses the evolution of provisions restricted to the cooperation between the parties and their national authorities towards more comprehensive arrangements, with clear and detailed obligations and even specific institutional mechanisms. ${ }^{57}$

Among the new subjects that the WTO agreements have not fully regulated, special attention needs to be drawn to the notable expansion of environmental provisions in Preferential Trade Agreements. This is a recent phenomenon in the history of PTAs' development. The creation of the North American Free Trade Agreement (NAFTA) stands out as one the first benchmarks in this direction. ${ }^{58}$

The NAFTA was one of the first PTAs to explicitly incorporate environmental concerns into a trade agreement. ${ }^{59}$ There is an attempt to balance the need of states to protect the environment and to expand free trade in the Chapter on Standard Related Measures and Agriculture and Phytosanitary Measures; by recognizing that the investment chapter should not be construed as preventing Parties from adopting and enforcing domestic environmental measures; and by incorporating certain MEAs ${ }^{60}$ into its provisions. ${ }^{61}$

Moreover, NAFTA was only adopted after the ac-

57 BADIN, Michelle; TASQUETTO, Lucas. Os Acordos de Comércio para Além das Preferências: uma Análise da Regulamentação sobre os Novos Temas. Revista de Direito Internacional, Brasília, v. 10, n. 1, p. 126, 2013.

58 BADIN, Michelle; AZEVEDO; Milena. A regulação de Meio Ambiente e Questões Trabalhistas nos Acordos Preferenciais de Comércio. In: OLIVEIRA, Ivan; BADIN, Michelle (Ed.). Tendências Regulatórias nos Acordos Preferenciais de Comércio no Século XXI: os casos de Estados Unidos, União Europeia, China e Índia. Brasília: IPEA, 2013. p. 297-298.

59 It is worth recalling that the European Integration Agreements also incorporated gradually environmental concerns. The 1957 Treaty establishing the European Economic Community - EEC (Treaty of Rome), for example, provided for in its article 36 that the commitments shall not be an obstacle to prohibitions or restrictions in respect of importation, exportation or transit, which are justified on grounds of the preservation of plant life.

60 Article 104 of NAFTA incorporate the following MEAs into its provisions: (i) the Convention on International Trade and Endangered Species of Wild Fauna and Flore (as amended June 22, 1979); the Montreal Protocol on Substances that Deplete the Ozone Layer (as amended June 29, 1990); and (iii) the Basel Convention on the Control of Transboundary Movements of Hazardous Wastes and Their Disposal.

61 TRUJILLO, Elizabeth. A Dialogical Approach to Trade and Environment. Journal of International Economic Law, Oxford, v. 16, n. 3, p. 562-563, Mar. 2013. 
ceptance of the North American Agreement on Environmental Cooperation (NAAEC), a side agreement established to provide environmental cooperation in the NAFTA implementation. ${ }^{62}$ Negotiated at the request of the United States, the NAAEC was a political necessity both to allay the fear of delocalization due to lax environmental standards and to ensure Congressional ratification. ${ }^{63}$ There was a preoccupation from the US that foreign investments would be displaced to Mexico where environmental standards were lower.

Even though the NAAEC has established a Commission for Environmental Cooperation (CEC) and its dispute settlement body, the Agreement has been more influential in cross-fertilizing environmental issues - for example, renewable electricity markets - at regional level than its adjudicatory function. ${ }^{64}$ The NAFTA model influenced significantly the adoption of subsequent PTAs negotiated by the United States. All recent North American PTAs devote entire chapters to environmental issues, including law enforcement and dispute settlement mechanisms. ${ }^{65}$

Usually, developed countries have been the primary drivers in including environmental provisions into PTAs. United States, Canada, New Zealand, and the European Union 'have been among the strongest proponents, both at the multilateral level and in PTAs. ${ }^{96}$ Developing countries, on the contrary, have been skeptical about including environmental provisions into trade agreements. Their preoccupation is that the trade-environment linkage might turn into an excuse to impose disguised protectionist measures. Even though the scope and depth of such provisions are not as elaborate as

62 KONG, Hoi; WROTH, L. Introduction: NAFTA and Sustainable Development. In: KONG, Hoi; WROTH, L. (Ed.). NAFTA and Sustainable Development. History, Experience and Prospects for Reform. Cambridge: Cambridge University Press, 2015. p. 1.

63 GAGNÉ, Gilbert; MORIN, Jean-Frédéric. The Evolving Policy on Investment protection: evidence from recent FTAs and the 2004 Model BIT. Journal of International Economic Law, Oxford, v. 9, n. 2, p. 379, May 2006.

64 TRUJILLO, Elizabeth. A Dialogical Approach to Trade and Environment. Journal of International Economic Law, Oxford, v. 16, n. 3, p. 565, Mar. 2013.

652012 U.S - Korea Free Trade Agreement (Article 20); 2012 U.S - Panama Free Trade Agreement (Article 17); 2009 U.S - Oman Free Trade Agreement (Article 17); 2009 U.S - Peru Free Trade Agreement (Article 17); 2006 U.S - Marocco Free Trade Agreement (Article 17).

66 ANURADHA, R. V. Environment. In: CHAUFFOUR, JeanPierre; MAUR, Jean-Christopher (Ed.). Preferential Trade Agreement. policies for development. Washington: World Bank, 2011. p. 408. those proposed by developed countries, 'countries such as Chile, China, and Mexico have been incorporating environmental provisions into their PTAs. ${ }^{97}$

From that angle, PTAs with environmental provisions are classified on the basis of three degrees of legal depth. ${ }^{68}$ Agreements in the first category introduce general provisions on cooperation in the realms of trade and the environment. Commitments are commonly found in a side agreement or in a Memorandum of Understanding. Similar type of PTA is usually adopted by China. The second category involves agreements that align provisions of cooperation with the establishment of minimum level of environmental protection and channels for public participation. The European Union PTAs signed until the beginning of the 2000s fall into this category. At last, the third category covers PTAs that go further on the provisions of cooperation by deepening their regulation through more substantive, detailed and binding commitments. Those features can be found in the US agreements and in the EU agreements signed after $2000 .{ }^{69}$

The Organization for Economic Co-operation and Development (OECD) has so far conducted one of the most comprehensive studies on the expansion of the environmental provision in Preferential Trade Agreements. The first OECDS's survey on this matter occurred in 2007 and aimed to analyze the types of environmental provisions, the ways they have been incorporated and the main incentives for adopting these provisions.

The 2007 Report recognized four main reasons (or policy drivers) for States to negotiate environmental issue in PTAs, that are: '(i) to contribute to the overarching goal of sustainable development; (ii) to ensure a level of playing field among Parties to the agreement; (iii) to enhance co-operation in environmental matters

67 ANURADHA, R. V. Environment. In: CHAUFFOUR, JeanPierre; MAUR, Jean-Christopher (Ed.). Preferential Trade Agreement. policies for development. Washington: World Bank, 2011.

68 BADIN, Michelle; AZEVEDO; Milena. A regulação de Meio Ambiente e Questões Trabalhistas nos Acordos Preferenciais de Comércio. In: OLIVEIRA, Ivan; BADIN, Michelle (Ed.). Tendências Regulatórias nos Acordos Preferenciais de Comércio no Século XXI: os casos de Estados Unidos, União Europeia, China e Índia. Brasília: IPEA, 2013. p. 299-300.

69 The 2011 European Union - South Korea Free Trade Agreement and the 2002 European Union - Chile Free Trade Agreement are examples of EU PTAs that falls into this third category due to their deeper commitments on trade-related environmental regulation. 
of shared interest; (iv) pursuing an international environmental agenda. ${ }^{30}$

Since then, this OECD study has been updated annually. Its last review disclosed on 25 July, 2014 evidences some interesting developments on the increase in environmental provisions in Preferential Trade Agreements. In accordance with the survey, the types of environmental provisions detected in PTAs are those related to: (i) a reference in the preamble; (ii) general and specific exceptions founded on GATT Article XX or GATS Article XIV for protection of human, animal and plant life; (iii) a commitment to upholding environmental law, and not weaken it to attract trade or investment; (iv) more environmental provisions, such as: environmental cooperation, public participation, dispute settlement, coverage of specific environmental issues, specific provisions on Multilateral Environmental Agreements (MEAs), and implementation mechanisms. ${ }^{71}$

Those provisions are incorporated either into the main text of the PTA or placed in separate side agreements. ${ }^{72}$ They may appear in specific chapters or under the cooperation chapter. Of note environmental and labor issues are often approached under the same chapter or even in the same clause. In some PTAs, the chapters are entitled social and sustainable development with a view to covering both issues. ${ }^{73}$ These commitments may appear as a blend of legally binding and nonbinding provisions. $^{74}$

In regard to emerging trends in terms of approach

70 GEORGE, Clive. Environment and Regional Trade Agreements: Emerging Trends and Policy Drivers. OECD Trade and Environment Working Papers, n. 2, 2014. Available at: <http:// www.oecd-ilibrary.org/trade/environment-and-regional-tradeagreements_5jz0v4q45g6h-en>. Accessed on: 10 Nov. 2016.

71 GEORGE, Clive. Environment and Regional Trade Agreements: Emerging Trends and Policy Drivers. OECD Trade and Environment Working Papers, n. 2, p. 7, 2014. Available at: <http:// www.oecd-ilibrary.org/trade/environment-and-regional-tradeagreements_5jz0v4q45g6h-en>. Accessed on: 10 Nov. 2016.

72 ANURADHA, R. V. Environment. In: CHAUFFOUR, JeanPierre; MAUR, Jean-Christopher (Ed.). Preferential Trade Agreement. policies for development. Washington: World Bank, 2011. p. 409.

73 BADIN, Michelle; AZEVEDO; Milena. A regulação de Meio Ambiente e Questões Trabalhistas nos Acordos Preferenciais de Comércio. In: OLIVEIRA, Ivan; BADIN, Michelle (Ed.). Tendências Regulatórias nos Acordos Preferenciais de Comércio no Século XXI: os casos de Estados Unidos, União Europeia, China e Índia. Brasília: IPEA, 2013. p. 297.

74 ANURADHA, R. V. Environment. In: CHAUFFOUR, JeanPierre; MAUR, Jean-Christopher (Ed.). Preferential Trade Agreement. policies for development. Washington: World Bank, 2011. p. 409. and wording adopted in PTAs' environmental provisions, there has been stressed (i) the expansion on the general exceptions; (ii) the inclusion of conflict clauses that ensure that obligations in other agreements take priority over the trade agreement; and (iii) the establishment of positive social obligations. ${ }^{75}$

Pursuant to 2014 OECD Survey, from 2007 to 2012, the total number of Preferential Trade Agreements containing environmental provisions that were in force amounted to $77 .^{76}$ The most common type of environmental provision in this sample of Agreements has been the exceptions based on GATT Article XX or GATS Article XIV for protection of human, animal and plant life. These provisions are an integral part of 60 of all Preferential Trade Agreements reviewed, $78 \%$ of them. The second most common type of environmental provision has been the reference to the environment or sustainable development in the Preamble, appearing in $52 \%$ of the PTAs reviewed. The third most common type of environment provision has been the mention of environmental cooperation, accounting for $49 \%$ of all PTAs. ${ }^{77}$

Of great significance the 2014 OECD research indicated an increase in the adoption of more substantive environmental provisions. In consonance with the report, these kinds of provisions remained constant up to 2010 at around 30\% of PTAs entering into force. They then rose to over 50\% in 2011 and near to $70 \%$ in 2012. Among them, the environmental cooperation clause has been the most common type, rising from $20 \%$ at the beginning of the study to almost $70 \%$ in $2012 .^{78}$

Thus, we can assert that recent international free tra-

75 BARTELS, Lorand. Social issues, environment and human rights. In: LESTER, Simon; MERCURIO, Bryan (Ed.). Bilateral and Regional Trade Agreements: commentary and analysis. New York: Cambridge University Press, 2009. p. 366.

76 GEORGE, Clive. Environment and Regional Trade Agreements: Emerging Trends and Policy Drivers. OECD Trade and Environment Working Papers, n. 2, p. 8, 2014. Available at: <http:// www.oecd-ilibrary.org/trade/environment-and-regional-tradeagreements_5jz0v4q45g6h-en>. Accessed on: 10 Nov. 2016.

77 GEORGE, Clive. Environment and Regional Trade Agreements: Emerging Trends and Policy Drivers. OECD Trade and Environment Working Papers, n. 2, 2014. Available at: <http:// www.oecd-ilibrary.org/trade/environment-and-regional-tradeagreements_5jz0v4q45g6h-en>. Accessed on: 10 Nov. 2016.

78 GEORGE, Clive. Environment and Regional Trade Agreements: Emerging Trends and Policy Drivers. OECD Trade and Environment Working Papers, n. 2, p. 9, 2014. Available at: <http:// www.oecd-ilibrary.org/trade/environment-and-regional-tradeagreements_5jz0v4q45g6h-en>. Accessed on: 10 Nov. 2016. 
de agreements have tended to enhance environmental cooperation among participating countries. Three factors particularly matter for developing regional environmental cooperative mechanisms, which are: (i) networks of intergovernmental organizations; (ii) the strong willingness of political leaders often embodied in national strategies for regionalism and (iii) the establishment and the institutionalized linkage - especially through FTAs - between trade and the environment. ${ }^{79}$

Although PTAs raise the possibility of addressing environmental issues beyond provisions of cooperation, 'trade and investment instruments promoting sustainable development goals can be adopted under PTA chapters on trade in goods, services, technical barriers to trade, sanitary and phytosanitary measures, government procurement, investment and technology transfer. ${ }^{90}$

Besides, another main innovation brought by the latest PTAs' generation lies in enforcing environmental obligations on the same basis as commercial provisions of the agreement - the identical remedies, procedures and sanctions. PTAs 'enforcement provisions make a meaningful addition to environmental obligations, above whatever exists in Multilateral Environmental Agreements and national laws. ${ }^{81}$

As observed, there has been a dizzying dissemination of environmental provisions in Preferential Trade Agreements in the last decade. In this context, special attention should be drawn to the negotiations of the so-called Mega Regional Trade Agreements. Due to their regulatory coverage and their geographical extension, these agreements may foreground a new paradigm for the protection of the environment through trade regulation.

\section{Trans-Pacific Partnership: A New Paradigm For Trade And Environment LINKAGE}

The negotiation of Mega Regional Trade Agreements (Mega-RTAs) is gradually rearranging the world trading system into large regional trading blocs gathering the world's main developed and developing countries. ${ }^{82}$ These agreements are 'deep integration partnerships between countries or regions with a major share of world trade and foreign direct investment (FDI), and in which two or more of the parties are a paramount driver position, or serve as hubs, in global values chains. ${ }^{83}$ In line with Draper, Lacey and Ramkolowan, those agreements can be defined as involving three features: (i) are negotiated by three or more countries or regional groupings; (ii) whose members collectively account for $25 \%$ or more of world trade; and (iii) the substance of which goes further the current WTO disciplines. ${ }^{84}$

While the majority of the Free Trade Agreements focus on creating preferential tariff regimes between countries over and above the W'TO's multilateral tariff levels, Palit reminds that Mega Regional Trade Agreements are aimed at deepening market-access gains beyond tariffs by harmonizing policies and regulations so as to influence cross-border movement of services, capital, people, technology, knowledge and ideas. ${ }^{85}$

A new way of governing world trade appears to be emerging. Even though the creation of the WTO in 1994 signaled a process of centralization of the world trading system that started with the adoption of GATT in 1947, the expansion of preferential trade agreements and the Mega Regional Trade Agreements over the last twenty years have reconfigured the governance in world trade. ${ }^{86}$

82 PALIT, Amitendu. Mega-RTAS and LDCs: Trade is not for the poor. Geoforum, Singapore, v. 58, p. 23, Jan. 2015.

83 MÉLENDEZ-ORTIZ, Ricardo. Mega-regionals: what is going on? In: WORLD ECONOMIC FORUM. Mega-Regional Trade Agreements: game-changers or costly distractions for the World Trading System? Geneva: World Economic Forum, 2014. p. 6.

84 DRAPER, Peter; LACEY, Simon; RAMKOLOWAN, Yash. Mega-Regional Trade Agreements: implications for the African, Caribbean and the Pacific Countries. ECIPE Occasional Paper, n. 2, p. 8, 2014. Available at: <http://www.ecipe.org/app/uploads/2014/12/ OCC22014_.pdf > . Accessed on: 20 Nov. 2016.

85 PALIT, Amitendu. Mega-RTAS and LDCs: Trade is not for the poor. Geoforum, Singapore, v. 58, p. 24, Jan. 2015.

86 AMARAL JÚNIOR, Alberto. Is Trade Governance Changing? Revista Brasileira de Direito Internacional, Brasília, v. 12, n. 2, p. 
If successfully adopted, Mega Regionals will have an extraordinary impact on how the international trade regime is governed. Or even if no mega-regional agreement succeeded, their negotiating objectives and ultimate stumbling blocks will shape the future of the WTO. ${ }^{87}$ Therefore, in view of understanding the trajectory of the environmental regulation under trade agreements, it is necessary to examine the Trans-Pacific Partnership (TPP). The first Mega-RTA to have its negotiations concluded.

Its Environment Chapter is the most far-reaching ever achieved in a trade agreement. It contains provisions on topics such as wildlife trade; marine fisheries; environmental goods and services; implementation of multilateral environmental agreements; access to remedies for environmental harm; transparency; cooperation; biodiversity; transition to a low-emission economy; corporate social responsibility and public-private partnerships. $^{88}$

The TPP introduces new features that are: (i) transparency requirements for fisheries subsidies programs and prohibition on some of the most harmful fisheries subsidies; (ii) broad commitments to promote sustainable fisheries management; and (iii) broad commitments to combat wildlife trafficking beyond the Convention on International Trade in Endangered Species of Wild Fauna and Flora (CITES). ${ }^{89}$

The Chapter's main purposes are to 'promote mutually supportive trade and environmental policies; promote high levels of environmental protection and effective enforcement of environmental laws; and enhance the capacities of the Parties to address trade-related environmental issues. ${ }^{30}$ Environmental law shall not be

379, 2015.

87 HUFBAUER, Gary; CIMINO-ISAACS, Catheleen. How will TPP and TTIP Change the WTO System? Journal of International Economic Law, Oxford, v. 18, p. 679, Aug. 2015.

88 UNITED STATES TRADE REPRESENTATIVE - USTR. Trans-Pacific Partnership: leveling the playing field for American workers \& American Businesses. Chapter 20 - Environment (TPP). Available at : <https://medium.com/the-trans-pacific-partnership/ environment-a7f25cd180cb\#.8mi33h9nz>. Accessed on: 16 Dec. 2016.

89 UNITED STATES TRADE REPRESENTATIVE - USTR. Trans-Pacific Partnership: leveling the playing field for American workers \& American Businesses. Chapter 20 - Environment (TPP). Available at : <https://medium.com/the-trans-pacific-partnership/ environment-a7f25cd180cb\#.8mi33h9nz>. Accessed on: 16 Dec. 2016.

90 TPP Art. 20.2 (1). used as disguised restriction to trade and investment, as well as the Parties shall not waive or derogate from its environmental law to encourage trade or investment. ${ }^{91}$

Even though the TPP might never enter into force due to the decision of the U.S president Donald Trump to withdraw the country from the Agreement, the language consensus on trade and environment protection achieved constitutes a new paradigm for the interplay between those two fields. The TPP's text is already being use to guide the discussions in this issue in all levels of negotiation. That is why its analysis still relevant.

\subsection{Implementation of Multilateral Environmental Agreements}

Regarding Multilateral Environmental Agreements (MEAs), the TPP countries affirmed their commitment to implement them to which they are already parties as well as to enhance the mutual supportiveness between trade and environmental law and policy. This should be undertaken especially through dialogue between relevant multilateral environmental agreements and trade agreements. $^{92}$

The Environment Chapter expressly reinforces the commitments foreseen in three MEAs ${ }^{93}$ : the Convention on International Trade in Endangered Species of Wild Fauna and Flora (CITES); the Montreal Protocol on Ozone Depleting Substances ${ }^{94}$; and the International Convention for the Prevention of Pollution from Ships (MARPOL). ${ }^{95}$ Even though the TPP provisions were based on those three MEAs, the CITES is the only expressly mentioned in the text of the Agreement. The Montreal Protocol and the MARPOL Convention are only referred in the footnotes. Not surprisingly, these three agreements are the only MEAs already commonly ratified by all the 12 Parties.

\footnotetext{
91 TPP Art 20.2(3) and 20.3(7).

92 TPP Art. 20.4.

93 Such commitment is quite similar to the one adopted under NAFTA (Article 104), except that in the latter, instead of MARPOL you find the 1989 Basel Convention on Control of Transboundary Movements of Hazardous Wastes and Their Disposal.

94 The Montreal Protocol was agreed on 16 September 1987 and entered into force on 1 January 1989. The treaty is designated to protect the ozone layer by phasing out the production of substances that are harmful to the ozone layer, causing its depletion.

95 The MARPOL Convention was adopted on 2 November 1973 and entered into force on 2 October 1983. The treaty covers the prevention of pollution of the marine environment by ships from operational or accidental causes.
} 
The CITES seeks to ensure that international trade in specimens of wild animals and plants does not threaten their survival, particularly by protecting endangered species (mostly located in developing countries) through the control of demand (from developed countries). ${ }^{96}$ The Convention was opened for signature in 1973 and entered into force on 1 July 1975. Approximately 5.600 species of animals and 30.000 species of plants are protected by CITES against over-exploitation through international trade. At the time of writing, 181 States are parties to the Convention. ${ }^{7}$

In order to achieve its goal, the CITES adopts mainly two approaches. The first one constitutes strictly regulating species that are threatened with extinction and which are or may be affected by trade. ${ }^{98}$ The second approach comprises ensuring that 'species that are not currently threatened with extinction do not become so as a result of un-controlled trade. ${ }^{99}$ Hence, 'CITES allows trade, but regulates it, in order to prevent extinction of animal and plant species. ${ }^{100}$

The TPP asserts that each Party shall adopt, maintain and implement laws, regulations and any other measures to fulfill its obligations under the CITES. ${ }^{101}$ The Parties further commit to: (a) take appropriate measures to protect and conserve wild fauna and flora that it has identified to be at risk within its territory; (b) maintain or strengthen government capacity and institutional frameworks to protect sustainable forest management and wild fauna and flora conservation; and (c) endeavor to develop and strengthen cooperation and consultation with interested non-governmental entities. ${ }^{102}$ The creation and participation in law enforcement networks are

96 DUPUY, Pierre-Marie; VIÑUALES, Jorge. International Environmental Law. Cambridge: Cambridge University Press, 2015. p. 398. 97 CITES Secretariat. Convention web-page. Available at: < https:// www.cites.org/eng>. Accessed on: 10 Dec. 2016.

98 TORPY, Renee. If Criminal Offenses Were Added to CITES, Would Nations be Better Able to Restrict International Trade in Endangered Species and Protect Biodiversity? Revista Brasileira de Direito Internacional, Brasília, v. 9, n. 3, p. 60, Dec. 2012.

99 TORPY, Renee. If Criminal Offenses Were Added to CITES, Would Nations be Better Able to Restrict International Trade in Endangered Species and Protect Biodiversity? Revista Brasileira de Direito Internacional, Brasília, v. 9, n. 3, p. 60, Dec. 2012.

100 TORPY, Renee. If Criminal Offenses Were Added to CITES, Would Nations be Better Able to Restrict International Trade in Endangered Species and Protect Biodiversity? Revista Brasileira de Direito Internacional, Brasília, v. 9, n. 3, p. 60, Dec. 2012.

101 TPP Art. 20.17 (2).

102 TPP Art. 20.17 (4). also encouraged. ${ }^{103}$

Hence, the TPP includes provisions to combat trade in wildlife, plants and fish - whether or not protected under CITES - if they have been taken illegally and if they have come from the TPP region. The scope of protection of endangered species of wild fauna and flora's protection is, therefore, extended beyond the established under the CITES.

Conservation of especially protected areas, such as wetlands and glaciers are also regulated under the TPP. ${ }^{104}$ A panel established under its Dispute Settlement Mechanism may also seek advice or assistance from an entity authorized in conformity with CITES to address a particular matter. ${ }^{105}$ The help of such entities could improve the balance of trade and environmental interests in commercial disputes.

The TPP strategy is direct: environmental abuses could be reduced if illegal trade in wild fauna and flora could be restricted more efficiently. These TPP provisions will directly bind the Parties to improve their sustainable management of biodiversity. However, it is worth noting that the sole reinforcement of CITES is not the ultimate solution for stopping trafficking of plants and animals. More comprehensive outcomes might be achieved if greater efforts to reduce the demand for these products in developed countries were carried out. ${ }^{106}$ It is worth noting that other key international treaties on biodiversity that cover issues addressed by the TPP were not reinforced by it, such as the 1949 Inter-American Tropical Tuna Convention, the 1946 International Convention for the Regulations of Whaling and the 1992 Convention on Biological Diversity $(\mathrm{CBD})^{107} \cdot{ }^{108}$

\section{TPP Art. 20.17 (7).}

104 UNITED STATES TRADE REPRESENTATIVE - USTR. Transatlantic Trade and Investment Partnership: TTIP Issue-by-Issue Environment. Available at: <https://ustr.gov/trade-agreements/ free-trade-agreements/transatlantic-trade-and-investment-partnership-t-tip/t-tip-9>. Accessed on: 16 Dec. 2016.

105 TPP Art. 20.23 (2).

106 SCHOTT, Jeffrey. TPP and the Environment. In: SCHOTT, Jeffrey; CIMINO-ISAACS, Cathleen (Ed.). Assessing the Trans-Pacific Partnership: innovations in trading rules. Washington: Peterson Institute for International Economics, 2016. p. 38.

107 Even though the United States signed the CBD in 1993, it never ratified it.

108 PEREIRA, Mariana Barreto. O Trans-Pacific Partnership Agreement e seus potenciais impactos para a regulação da biodiversidade no âmbito transnacional. Revista de Direito Internacional, Brasília, v. 13, n. 2, p. 377-391, 2016. 
As regards to the Montreal Protocol, TPP Environment Chapter determines that its Parties 'shall take measures to control the production and consumption of and trade in, [substances that deplete the ozone layer]. ${ }^{109}$ The Agreement's Annex 20-A keeps a record of the measures currently applied by the Parties that are deemed to comply with this obligation. Furthermore, the TPP recommends ${ }^{110}$ its Partners to cooperate on matters such as environmentally friendly alternatives to ozone-depleting substances and the combating of illegal trade in those products. ${ }^{111}$ The content behind these rules will have a direct effect in the industry of the TPP Parties, which will have to adapt and improve its market approaches to substitute substances that deplete the ozone layer in a wide range of industrial and consumer applications.

With respect to protection of the marine environment, the TPP establishes provisions on the prevention of pollution from ships, including cooperation in enforcement measures by the flag State or, as appropriate, by the port State. ${ }^{112}$ The strengthening of these provisions grounded in the MARPOL Convention will have a direct impact in the regional shipping industry. The Parties' flag State vessels will probably face new obligations regarding accidental or deliberate pollution; and increased protection in special geographic areas.

\subsection{Fisheries Subsidies}

Total fisheries subsidies are estimated to amount to approximately 'US\$35 billion, which constitutes 30$40 \%$ of the landed values generated by wild fisheries worldwide. ${ }^{113}$ The highest share of them (about US $\$ 20$ billion) is constituted by capacity-enhancing subsidies. Destructive fishing practices and fleet overcapacity are enabled by those government subsidies. ${ }^{114}$

\section{TPP Art. 20.5 (1).}

110 TPP Art. 20.5 (3).

111 SCHOT'T, Jeffrey. TPP and the Environment. In: SCHOTT, Jeffrey; CIMINO-ISAACS, Cathleen (Ed.). Assessing the Trans-Pacific Partnership: innovations in trading rules. Washington: Peterson Institute for International Economics, 2016. p. 36.

112 TPP Art. 20.6.

113 SUMAILA, Rashid. Trade Policy Options for Sustainable Oceans and Fisheries. E15 Expert Group on Oceans, Fisheries and Trade System - Policy Options Paper, REF 181215. p. 6. Available at: <http://www3.weforum.org/docs/E15/WEF_Fisheries_report_2015_1401.pdf>. Accessed on: 16 Dec. 2016.

114 SUMAILA, Rashid. Trade Policy Options for Sustainable Oceans and Fisheries. E15 Expert Group on Oceans, Fisheries
The TPP seeks to control, reduce and eventually eliminate all subsidies that contribute to overfishing and overcapacity. Therefore, no Party shall grant or maintain any: (a) subsidies for fishing that negatively affect fish stocks that are in an overfished condition; and (b) subsidies provided to any fishing vessel while listed by the flag State or Regional Fisheries Management Organization or Arrangement for illegal, unreported and unregulated (IUU) fishing. ${ }^{115}$ Subsidy programs that were created before the TPP's conclusion shall be brought into conformity as soon as possible and no later than three years after the date of entry into force of the Agreement. ${ }^{116}$ Each Party shall also report regularly to the other TPP Parties the details of its fisheries subsidies programs. ${ }^{117}$

Fisheries subsidies regulation is a major TPP achievement, considering that its Parties rank among the world's largest fish exporters and the subsidies provided by some of them contribute substantially to overfishing. ${ }^{118}$ Nevertheless, the TPP provisions are only a similar version of the main Treaty on the matter, the 2009 Food and Agriculture Organization (FAO) Agreement on Port State Measures to Prevent, Deter, and Eliminate Illegal Unreported and Unregulated Fishing. The TPP is less comprehensive and binding than 2009 Agreement and it does not require its Parties to adopt and implement it. The Port State Measures ${ }^{119}$ has not yet entered into force because it is pending ratification by a minimum number of signatories. ${ }^{120}$

and Trade System - Policy Options Paper, REF 181215. Available at: <http://www3.weforum.org/docs/E15/WEF_Fisheries_report_2015_1401.pdf>. Accessed on: 16 Dec. 2016.

115 TPP Art. 20.16 (5).

116 TPP Art. 20.16 (6).

117 These notifications shall contain information such as: program name; legal authority for the program; catch data by species in the fishery for which the subsidy is provided; status of the fish stocks in the fishery for which the subsidy is provided, fleet capacity in the fishery for which the subsidy is provided; conservation and management measures in place for the relevant fish stock; and total imports and exports per species (TPP art 20.16 (10)).

118 SCHOTT, Jeffrey. TPP and the Environment. In: SCHOTT, Jeffrey; CIMINO-ISAACS, Cathleen (Ed.). Assessing the Trans-Pacific Partnership: innovations in trading rules. Washington: Peterson Institute for International Economics, 2016. p. 34.

119 The United States ratified the 2009 FAO Agreement on Port State Measures to Prevent, Deter, and Eliminate IUU Fishing in February 2016.

120 SCHOTT, Jeffrey. TPP and the Environment. In: SCHOTT, Jeffrey; CIMINO-ISAACS, Cathleen (Ed.). Assessing the Trans-Pacific Partnership: innovations in trading rules. Washington: Peterson Institute for International Economics, 2016. p. 35. 
In the multilateral realm, the Doha Declaration assigned the issue of fishing subsidies to the 'Rules' Negotiating Group, which is entitled to negotiate amendments to the WTO Agreement on Subsidies and Countervailing Measures (SCM). However, over a decade later, the group of Member Countries led by the United States (known as Friends of Fish) did not achieve any substantive outcome on the matter, ${ }^{121}$ especially, because of 'fundamental disagreements over the respective level of commitments expected from emerging countries and more advanced economies. ${ }^{122}$

In 2006, the U.S Congress allowed the shift of its fish protection efforts to regional and bilateral forums through the amendment of its primary law governing marine fisheries, the Magnuson-Stevens Fishery Conversation and Management Act. The regulation of this subject under the TPP is a direct result of this policy. ${ }^{123}$ The language adopted in the Agreement will probably light the way for a WTO multilateral agreement on fisheries subsidies. Its provisions on the subject are likely to be used as a model for the negotiations in the next Ministerial Conference in Argentina in 2017.

The TPP also foresees other broader commitments on marine fisheries protection. The Parties shall seek to operate a fisheries management system that is designed to: (a) prevent overfishing and overcapacity; (b) reduce by-catch of non-target species and juveniles, and (c) promote the recovery of overfished stocks for all marine fisheries in which that Party's persons conduct fishing activities. ${ }^{124}$ More precisely, the Environment Chapter sets forth that each Party shall promote the long-term conservation of sharks, marine turtles and marine mammals. ${ }^{125}$ These obligations were particularly sensitive for many Asian negotiating countries that have

121 GLASS-O’SHEA, Brooke. Watery Grave: Why International and Domestic Lawmakers need to do More to Protect Oceanic Species From Extinction. West Northtwest, San Francisco, v. 17, n. 2, p. 116, 2011.

122 SUMAILA, Rashid. Trade Policy Options for Sustainable Oceans and Fisheries. E15 Expert Group on Oceans, Fisheries and Trade System - Policy Options Paper, REF 181215. p. 14. Available at: <http://www3.weforum.org/docs/E15/WEF_Fisheries_report_2015_1401.pdf>. Accessed on: 16 Dec. 2016.

123 UNITED STATES NATIONAL OCEANIC AND ATMOSPHERIC ADMINISTRATION. Implementation of Title IV of the Management Reauthorization Act of 2006. Available at: <http:// www.nmfs.noaa.gov/ia/iuu/msra_page/2009_report.pdf>. Accessed on: 5 Dec. 2016.

124 TPP Art. 20.16 (3).

125 TPP Art. 20.16 (4). the custom of eating these animals as national delicacy.

\subsection{Public-Private Partnership}

With regard to voluntary mechanisms to enhance environmental performance and public-private partnerships (PPPs), the TPP Parties recognized the importance of those mechanisms to achieve and maintain high levels of environmental protection and complement domestic regulatory measures. They should be designed in a manner that avoids the institution of unnecessary barriers to trade and boost environmental benefits. ${ }^{126}$

Through the mobilization and sharing of knowledge, expertise, technology and financial resources, PPPs can be an important tool to achieve sustainable. They can be designed to provide incentive to the private sector to adopt sustainable criteria in the conduction of its business. Without the responsible, participative and active involvement of the private sector, the current environmental challenges cannot be overcome. ${ }^{127}$ In this sense, the TPP encourages to the formation of new partnerships between the public and the private sector.

\subsection{Committee on Environment}

The Transpacific Partnership created a Committee composed of senior government representatives responsible for the implementation of the Environment Chapter. ${ }^{128}$ The Committee is competent to: (i) provide a forum to discuss and review the implementation of the Chapter; (ii) provide periodic reports to the TPP Commission; (iii) and provide a forum to discuss and review activities. ${ }^{129}$ All decisions and reports of the Committee shall be made by consensus and be made available to the public, unless agreed otherwise. ${ }^{130}$

On the matter of trade in environmental goods and services, the senior-level Environment Committee shall consider issues identified as potential non-tariff barriers to trade. ${ }^{131}$ The Parties may also engage in bilateral and plurilateral cooperative projects on environmental goo-

\footnotetext{
126 TPP Art. 20.11 (1).

127 UNITED NATIONS INSTITUTE FOR TRAINING AND RESEARCH. Annemasse Declaration. Available at: <http://www.unppp.org/annemasse-declaration>. Accessed on: 5 Nov. 2016.

128 TPP Art. 20.19 (2).

129 TPP Art. 20.19 (3).

130 TPP Art. 20.19 (5) and (6).

131 TPP Art. 20.18 (3).
} 
ds and services. ${ }^{132}$ Even though such initiatives are key to unlock renewable energy production among Parties and facilitate action on climate change, no specific commitment on trade in environmental goods and services was achieved. The issue was delegated to the Committee to conduct further consultations.

In addition, the Environment Committee makes possible that TPP Members name and shame countries that do not implement or enforce policies that are not legally binding in the Agreement. ${ }^{133}$ For example, even though the TPP does not expressly prohibits shark finning because its Article 20.16 states that countries 'should' ban these practices, the TPP Environment Committee could use peer pressure to change such a policy. The successful implementation of the TPP environmental provisions will much depend upon the Parties' voluntary efforts to make the most of them. ${ }^{134}$

The TPP's Committee on Environment is a good example of institutional design that could enhance the compliance with the trade-related environmental rules. Even though the TPP might never come into force, this institutional model could be replicated in other PTAs. Such a forum is of key importance in the constant monitoring, reviewing and improvement of environmental obligations agreed under a PTA's framework.

\subsection{Dispute Settlement}

Obligations on the TPP's Environment Chapter will be enforced through the same dispute settlement procedures and mechanisms accessible for other disputes arisen under other TPP Chapters. Thus, the Parties may apply trade sanctions when environmental obligations have been breached. ${ }^{135}$ In this aspect, the TPP is more comprehensive than the dispute settlement systems of

132 TPP Art. 20.18 (4).

133 SCHOTT, Jeffrey. TPP and the Environment. In: SCHOTT, Jeffrey; CIMINO-ISAACS, Cathleen (Ed.). Assessing the Trans-Pacific Partnership: innovations in trading rules. Washington: Peterson Institute for International Economics, 2016. p. 35.

134 RIMMER, Matthew. Greenwashing the Trans-Pacific Partnership: Fossil Fuels, the Environment and Climate Change. Santa Clara Journal of International Law, Santa Clara, v. 14, n. 2, p. 502, May 2016.

135 UNITED STATES TRADE REPRESENTATIVE - USTR. Trans-Pacific Partnership: leveling the playing field for American workers \& American Businesses. Chapter 20 - Environment (TPP). Available at : <https://medium.com/the-trans-pacific-partnership/ environment-a7f25cd180cb\#.8mi33h9nz>. Accessed on: 16 Dec. 2016. the WTO and the NAFTA. Neither of them allow for the resolution of issues regarding environment provisions in such an objective and direct manner. ${ }^{136}$ The TPP might then build its own jurisprudence on this new regulated subject.

However, before taking a controversy to the TPP's dispute settlement system, the Parties agreed to conduct three levels of consultations. ${ }^{137}$ Only if the (i) parties consultation, (ii) the senior representative consultations and the (iii) ministerial consultations have failed to solve the problem, the requesting Party may require the establishment of a panel under the TPP dispute settlement system. ${ }^{138}$

TPP's Dispute Settlement Chapter also innovates insofar as the panels shall be composed not only of international trade experts, but also of experts on the matter of the dispute. ${ }^{139}$ In this connection, environmental experts may compose a panel that appreciates trade disputes involving environmental issues. This opens the possibility of a more balanced decision without a purely commercial bias. It is argued that the lack of environmental experts in trade disputes involving environmental issues overshadows the preservation of natural resources in detriment of the trade agreement's economic scope. ${ }^{140}$

It is worth noting that, the commitments made by the Parties under the Multilateral Environmental Agreements to which they have joined are also subjected to

136 HILLMAN, Jennifer. Dispute Settlement Mechanism. In: SCHOTT, Jeffrey; CIMINO-ISAACS; Cathleen (Ed.). Assessing the Trans-Pacific Partnership: innovations in trading rules. Washington: Peterson Institute for International Economics, 2016. p. 102.

137 A Party may request consultations with any other Party regarding any matter arising under the Environmental Chapter by delivering a written request to the responding Party's contact point. This consultation request shall circulate to the other Parties that may participate in the consultations if they consider that they have substantial interest in the matter discussed (TPP Article 20.20). If the involved Parties have failed to resolve the matter, a committee of senior representatives shall be called to address the issue. They may gather relevant scientific and technical information from governmental e non-governmental experts (TPP Article 20.21). If the senior representative consultations have failed, the Parties shall refer the matter to their respective Ministers (TPP Article 20.22). Failing all three levels of consultation, the Party may request the establishment of a panel.

138 TPP Art. 20.23.

139 TPP Art. 28.10.

140 PEREIRA, Mariana Barreto. O Trans-Pacific Partnership Agreement e seus potenciais impactos para a regulação da biodiversidade no âmbito transnacional. Revista de Direito Internacional, Brasília, v. 13, n. 2, p. 385-386, 2016. 
the same dispute settlement procedure as commercial obligations under the TPP. This will helps to ensure that countries do not waive or weaken their obligations under MEAs in order to attract trade or investment and that a country faces consequences if it does weaken its safeguards. ${ }^{141}$ Besides, this legal scheme grants teeth to MEAS that lacks biding enforcement regimes.

It should be noted that TPP's developing countries were very skeptical about the adoption of binding dispute settlement procedures for environmental obligations. Nonetheless, United States accomplish to overcome such reluctance by softening other clauses (i.e, 'should' instead of 'shall') in exchange of this possibility. ${ }^{142}$ If the TPP one day comes into force, it remains to be seen if countries will really bring trade dispute against a Party, which fails to live up to its environmental obligations in a trade deal. The United States, for example, did not take action under the US - Peru Trade Promotion Agreement to combat illegal logging, even when there was documented evidence of non-compliance with environmental obligations. ${ }^{143}$

The use of trade sanctions in response to environmental provisions' violations has been historically criticized by developing countries. They have argued that, due to the current significant discrepancy between the levels of environmental protection between developing and developed countries, only the latters would able to make full use of this mechanism in practice. On this view, developed countries would be virtually immune to this kind of trade sanctions, since they already have a sound established environmental protection system with well functioning institutions and effective rules. The implementation of environmental obligations is costly and demands high expenditures on infrastructure and human capacity building. Developing countries argue that commercially sanctioning countries that have not achieved to comply with these rules is not the best approach to incentivize national sustainable policies.

141 RIMMER, Matthew. Greenwashing the Trans-Pacific Partnership: Fossil Fuels, the Environment and Climate Change. Santa Clara Journal of International Law, Santa Clara, v. 14, n. 2, p. 498, May 2016.

142 SCHOTT, Jeffrey. TPP and the Environment. In: SCHOTT, Jeffrey; CIMINO-ISAACS, Cathleen (Ed.). Assessing the Trans-Pacific Partnership: innovations in trading rules. Washington: Peterson Institute for International Economics, 2016. p. 33-34.

143 RIMMER, Matthew. Greenwashing the Trans-Pacific Partnership: Fossil Fuels, the Environment and Climate Change. Santa Clara Journal of International Law, Santa Clara, v. 14, n. 2, p. 503, May 2016.
They defend that greater emphasis should be put on cooperation, technology transfer and technical assistance initiatives.

\subsection{Other Environment-Related Provisions}

It is also important to stress that environmental provisions are not restricted to the TPP's Environment Chapter. Its Investment and Intellectual Property Chapters also set forth substantial clauses on the issue. For instance, nothing in the TPP Investment Chapter shall be construed to prevent a country from adopting, maintaining or enforcing any measure that it considers appropriate to ensure that investment activity in its territory is undertaken in a manner sensitive to environmental objectives. ${ }^{144}$

Moreover, the Investment Chapter determines that 'non-discriminatory regulatory actions by a Party that are designed and applied to protect legitimate public welfare objectives, such as $[\ldots]$ the environment do not constitute indirect expropriations except in rare circumstances. ${ }^{145}$ Accordingly, to prove that an environmental measure constitutes an indirect expropriation, the Party should carry out a case-by-case inquiry that considers: (i) the economic impact of the government action; (ii) the extent to which the government action interferes with reasonable investment-backed expectations; (iii) and the character of the government action. ${ }^{146}$ In addition, it makes up of an indispensable attitude to prove that an environmental measure was not applied in a discriminatory manner.

This commitment intends to avoid that corporations use the Investor-State Dispute Settlement (ISDS) carved out under Transpacific Partnership to challenge environmental policies and other regulatory initiatives protecting the environment. This reflects an old claim raised by environmental groups fearful that ISDS litigation might outweigh the environmental gains of the TPP. ${ }^{147}$

Furthermore, the Intellectual Property Chapter determines that a Party may exclude an invention from

\footnotetext{
144 TPP Art. 9.15.

145 TPP Annex 9-B, paragraph 3 (b).

146 TPP Annex 9-B, paragraph 3 (a).

147 SCHOT'T, Jeffrey. TPP and the Environment. In: SCHOT'T, Jeffrey; CIMINO-ISAACS, Cathleen (Ed.). Assessing the Trans-Pacific Partnership: innovations in trading rules. Washington: Peterson Institute for International Economics, 2016. p. 34.
} 
patentability when necessary to protect 'ordre public or morality, including to protect human, animal or plant life or health or to avoid serious prejudice to nature or the environment. ${ }^{148}$ Therefore, a Party may prevent the commercial exploitation within its territory of a patent that may harm the environment or put the life or health of humans, animals and plants in danger. That provision is also mentioned by the TRIPS Agreement (Article 27.2).

\subsection{TPP's Limitations and Achievements}

The Transpacific Partnership fails to establish a framework that fosters the transfer of green technology to combat global warming, particularly of renewable energy. The expression 'climate change is not even mentioned in the Agreement, because the US negotiators bowed to demands from skeptical members of Congress who threatened to vote against the entire pact if [those words] appeared in the text. ${ }^{149}$ To replace it, the negotiators entitled the section Transition to a Low Emissions and Resilient Economy that does not dedicate the necessary funding to carry out activities to address the issue, being unlikely to be translated into effective actions. ${ }^{150}$

Actually, there are concerns that the commitments under the TPP might work against the efforts to combat climate change. The reduction and elimination of tariffs and service barriers related to the oil and gas sector could increase trade in fossil fuels and enable the expansion of the American fracking industry throughout the Pacific Rim. The TPP's timid effort to promote clean energy policies will probably be counteracted by more trade in fossil fuels. The TPP's weak language on climate change falls short to address one of the most pressing environmental problems of our time.

However, the TPP remains the most important and extensive preferential trade agreement until the present moment that deals directly with the interplay between

\footnotetext{
148 TPP Art. 18.37 (3).

149 SCHOTT, Jeffrey. TPP and the Environment. In: SCHOTT, Jeffrey; CIMINO-ISAACS, Cathleen (Ed.). Assessing the Trans-Pacific Partnership: innovations in trading rules. Washington: Peterson Institute for International Economics, 2016. p. 39.

150 SCHOT'T, Jeffrey. TPP and the Environment. In: SCHOT'T, Jeffrey; CIMINO-ISAACS, Cathleen (Ed.). Assessing the Trans-Pacific Partnership: innovations in trading rules. Washington: Peterson Institute for International Economics, 2016.
}

trade and environmental protection. Besides, the TPP represents an ambitious leap forward since it is the first time for the majority of the TPP countries that they include an environment chapter and environmental goals in their PTAs. ${ }^{151}$ This is particularly relevant for countries that make up of more than one third of global fisheries catch and are the home to roughly one third of the world's threatened species. ${ }^{152}$

\section{Final Conclusions}

The Transpacific Partnership is the most advanced Preferential Trade Agreement in terms of environmental provisions already concluded. There is no trade agreement currently in force that matches its Environment Chapter in terms of breadth and depth of obligations and dispute settlement procedures. Even though the TPP might never enter into force due to Donald Trump's decision to withdraw the United States from the Agreement, its treaty language reflects important consensus between developing and developed countries on rules designed to enhance the mutual supportiveness between trade and environmental protection.

The TPP contains binding provisions and enforcement mechanisms that allow the imposition of trade sanctions in case of an environmental obligation have been breached. This gives greater effectiveness to the commitments agreed upon the Environment Chapter and enhances national standards of environmental protection.

In addition, some Multilateral Environmental Agreements adopted by the TPP Parties also could gain real teeth, since the obligations agreed upon were subjected to the Dispute Settlement System established under the Transpacific Partnership. This could be a relevant boost in the effectiveness of some MEAs that only have weak enforcement mechanisms.

The TPP's Dispute Settlement System also provides for the participation of specialists other than trade ex-

151 LURIÉ, Andrew; KALININA, Maria. Protecting Animals in International Trade: a Study of the Recent Successes at the WTO and in Free Trade Agreements. The American University Law Review, Washington, v. 30, n. 3, p. 474, 2015.

152 LURIÉ, Andrew; KALININA, Maria. Protecting Animals in International Trade: a Study of the Recent Successes at the WTO and in Free Trade Agreements. The American University Law Review, Washington, v. 30, n. 3, p. 472, 2015. 
perts in the panel's composition. As a consequence, trade disputes concerning environmental issues may also count with the presence of environmental experts. This could diminish the trade bias, normally found in the WTO decisions and render them more balanced with environmental precepts.

The TPP goes beyond the CITES by taking enhanced actions to combat wildlife trafficking - regardless of whether the wildlife is protected under CITES. The Partnership requires its Party to implement its CITES obligations and effectively enforce its laws and regulations, including commitments to cooperate by sharing information relevant to inquiry of criminals engaged in wildlife trafficking.

The Partnership addresses the sensitive issue of fish subsidies, providing innovative and concrete alternatives that should diminish the destructive effects of this practice. The TPP Parties agreed to gradually reduce and, eventually, eliminate the most harmful subsidies that are one of the main causes of overfishing and make their fisheries subsidies programs more transparent. Such initiatives could help to build up language that can light the way for WTO negotiations on this matter. The regulation of fishing subsidies under the TPP is a good example of how common environmental problems are more easily addressed in regional efforts than in global forums.

Even though the TPP covers a wide range of environmental issues, it does not address other urgent environmental challenges such as global warming. The 'Transition to a Low Emissions and Resilient Economy' clause is only a euphemism for taking real action in mitigating greenhouse gas emissions. The core subjects, such as environmental technologies, renewable energies and subsidies were not regulated. There is only a possible list of cooperation initiatives. There were, in fact, concerns that the TPP could actually facilitate trade in fossil fuels and the expansion of fracking industry in the Asia-Pacific Region. Preventive measures to counterbalance such side effects should have been put in place within the Agreements' implementation exercise.

The reasons why the TPP chose to protect some environmental aspects and neglected others are based on the Parties' capacity to build consensus in sensitive issues that, after all, still have to be approved by the legislative powers of all signatory countries. Considering that the TPP constitutes an agreement mainly driven by the United States, the advancements in its trade-related environmental clauses display the U.S priorities and beliefs that could not be achieved at the multilateral level.

Taking into account the abovementioned arguments, we can assert that incorporation of environmental provisions in the Transpacific Partnership has assumed growing importance in the efforts to render international trade and environmental protection mutually supportive and to achieve the sustainable development goals. However, the TPP's analysis demonstrated that environmental consequences of the implementation of preferential trade agreements should be further assessed. Complementary studies should be undertaken to analyze the environmental consequences of the implementation of preferential agreements as a whole. This would allow the elaboration of preventive measures to overcome possible side effects, such as the increase of trade in fossil fuels or the reallocation of pollution intensive industries, due to the other trade liberalization provisions.

\section{REFERENCES}

AMARAL JÚNIOR, Alberto. Comércio Internacional e Proteção do Meio Ambiente. São Paulo: Atlas, 2011.

AMARAL JÚNIOR, Alberto. Is Trade Governance Changing? Revista Brasileira de Direito Internacional, Brasília, v. 12, n. 2, p. 371-382, 2015.

ANURADHA, R. V. Environment. In: CHAUFFOUR, Jean-Pierre; MAUR, Jean-Christopher (Ed.). Preferential Trade Agreement: policies for development. Washington: World Bank, 2011.

BACCINI, Leonardo; DÜR, Andreas. The New Regionalism and Policy Interdependence. British Journal of Political Science, Cambridge, v. 42, n. 1, p. 57-79, jun. 2011.

BADIN, Michelle; AZEVEDO; Milena. A regulação de Meio Ambiente e Questões Trabalhistas nos Acordos Preferenciais de Comércio. In: OLIVEIRA, Ivan; BADIN, Michelle (Ed.). Tendências Regulatórias nos Acordos Preferenciais de Comércio no Século XXI: os casos de Estados Unidos, União Europeia, China e Índia. Brasília: IPEA, 2013.

BADIN, Michelle; TASQUETTO, Lucas. Os Acordos de Comércio para Além das Preferências: uma Análise da Regulamentação sobre os Novos Temas. Revista de 
Direito Internacional, Brasília, v. 10, n. 1, p. 105-126, 2013.

BALDWIN, Richard. $21^{\text {st }}$ Century Regionalism: filling the gap between $21^{\text {st }}$ century trade and $20^{\text {th }}$ century trade rules. WTO Staff Working Paper ERSD-2011-08. Available at: <https://www.wto.org/english/res_e/reser_e/ ersd201108_e.pdf>. Accessed on: 16 Nov. 2016.

BARTELS, Lorand. Social issues, environment and human rights. In: LESTER, Simon; MERCURIO, Bryan (Ed.). Bilateral and Regional Trade Agreements: commentary and analysis. New York: Cambridge University Press, 2009.

BIRKBECK, Carolyn Deere; BOTWRIGHT, Kimberley. The Future of the Global Trade and Investment Architecture: Pursuing Sustainable Development in the Global Economy - Overview of Issues, Challenges and Debates. Geneva: International Centre for Trade and Sustainable Development and World Economic Forum, 2015.

CAUBET, Christian Guy. A Irresistível Ascensão do Comércio Internacional: o meio ambiente fora da lei? Revista de direito Ambiental, São Paulo, v.6, p. 81-99, abr./ jun. 2001.

CITES Secretariat. Convention web-page. Available at: $<$ https://www.cites.org/eng >. Accessed on: 10 Dec. 2016.

COT'TIER, Thomas; HOLZER, Kateryna. Addresssing Climate Change under Preferential Trade Agreements: towards alignment of carbon standards under the Transatlantic Trade and Investment Partnership. Global Environmental Change, v. 35, p. 514-244, Jul. 2015.

DRAPER, Peter; LACEY, Simon; RAMKOLOWAN, Yash. Mega-Regional Trade Agreements: implications for the African, Caribbean and the Pacific Countries. ECIPE Occasional Paper, n. 2, 2014. Available at: <http:// www.ecipe.org/app/uploads/2014/12/OCC22014_. pdf>. Accessed on: 20 Nov. 2016.

DUPUY, Pierre-Marie; VIÑUALES, Jorge. International Environmental Law. Cambridge: Cambridge University Press, 2015.

FRANKEL, Jeffrey. Environmental Effects of International Trade. Västerås: Sweden's Globalisation Council, 2009.

GAGNÉ, Gilbert; MORIN, Jean-Frédéric. The Evolving Policy on Investment protection: evidence from recent FTAs and the 2004 Model BIT. Journal of International Economic Law, Oxford, v. 9, n. 2, p. 357-382, May 2006.
GEMMILL, Barbara; BAMIDELE-IZU, Abimbola. The role of NGOs and Civil Society in Global Environmental Governance. In: ESTY, Daniel C; IVANNOVA, Maria H. (Ed.). Global environmental governance: Options and opportunities. New Haven: Yale School of Forestry \& Environmental Studies, 2002.

GEORGE, Clive. Environment and Regional Trade Agreements: Emerging Trends and Policy Drivers. OECD Trade and Environment Working Papers, n. 2, 2014. Available at: <http://www.oecdilibrary.org/trade/ environment-and-regional-tradeagreements_5jz0v4q45g6h-en>. Accessed on: 10 Nov. 2016.

GLASS-O'SHEA, Brooke. Watery Grave: Why International and Domestic Lawmakers need to do More to Protect Oceanic Species From Extinction. West Northtwest, San Francisco, v. 17, n. 2, p. 101-142, 2011.

HILLMAN, Jennifer. Dispute Settlement Mechanism. In: SCHOT'T, Jeffrey; CIMINO-ISAACS; Cathleen (Ed.). Assessing the Trans-Pacific Partnership: innovations in trading rules. Washington: Peterson Institute for International Economics, 2016.

HOWSE, Robert. The Appellate Body Ruling in the Shrimp/Turtle Case: A New Legal Base Line for the Trade and Environment Debate. Columbia Journal of International Law, v. 27, n. 2, p. 491-521, 2002.

HUFBAUER, Gary; CIMINO-ISAACS, Catheleen. How will TPP and TTIP Change the WTO System? Journal of International Economic Law, Oxford, v. 18, p. 679-696, Aug. 2015.

KONG, Hoi; WROTH, L. Introduction: NAFTA and Sustainable Development. In: KONG, Hoi; WROTH, L. (Ed.). NAFTA and Sustainable Development. History, Experience and Prospects for Reform. Cambridge: Cambridge University Press, 2015.

LOWENFELD, Andreas. International Economic Law. 2. ed. Oxford: Oxford University Press, 2011.

LURIÉ, Andrew; KALININA, Maria. Protecting Animals in International Trade: a Study of the Recent Successes at the WTO and in Free Trade Agreements. The American University Law Review, Washington, v. 30, n. 3, p. 431-487, 2015.

MATIAS, João Luis Nogueira; ZANOCCHI, José Maria McCall. A Compatibilização entre o Comércio Internacional e a Proteção do Meio Ambiente no Âmbito 
da OMC: Análise do Caso das Restrições à Importação de Pneus Recauchutados pelo Brasil. Anais do XX Encontro Nacional do CONPEDI, Florianópolis: Fundação Boiteux, p. 4994-5016, 2011.

MÉLENDEZ-ORTIZ, Ricardo. Mega-regionals: what is going on? In: WORLD ECONOMIC FORUM. Mega-Regional Trade Agreements: game-changers or costly distractions for the World Trading System? Geneva: World Economic Forum, 2014.

ORGANIZATION FOR ECONOMIC COOPERATION AND DEVELOPMENT. The Environmental Effects of Trade. Paris: OECD Publications, 1994.

PALIT, Amitendu. Mega-RTAS and LDCs: Trade is not for the poor. Geoforum, Singapore, v. 58, p. 23-26, Jan. 2015.

PEREIRA, Mariana Barreto. O Trans-Pacific Partnership Agreement e seus potenciais impactos para a regulação da biodiversidade no âmbito transnacional. Revista de Direito Internacional, Brasília, v. 13, n. 2, p. 377-391, 2016.

PINDYCK, Robert; RUBINFELD, Daniel. Microeconomia. São Paulo: Makron Books, 1994.

QUEIROZ, Fábio Albergaria. Meio ambiente e comércio internacional: relação sustentável ou opostos inconciliáveis? Argumentos ambientalistas e pró-comércio do debate. Contexto Internacional, Rio de Janeiro, v. 31, n. 2, p. 251-283, maio/ago. 2009.

RIMMER, Matthew. Greenwashing the Trans-Pacific Partnership: Fossil Fuels, the Environment and Climate Change. Santa Clara Journal of International Law, Santa Clara, v. 14, n. 2, p. 488-542, May 2016.

ROLLO, Jim. The Challenge of Negotiating RTAs for Developing Countries: what could the WTO do to help? In: BALDWIN, Richard; LOW, Patrick (Ed.). Multilateralizing Regionalism: Challenges for the Global Trading System. Cambridge: Cambridge University Press, 2009.

SCHOTT, Jeffrey. TPP and the Environment. In: SCHOTT, Jeffrey; CIMINO-ISAACS, Cathleen (Ed.). Assessing the Trans-Pacific Partnership: innovations in trading rules. Washington: Peterson Institute for International Economics, 2016.

SUMAILA, Rashid. Trade Policy Options for Sustainable Oceans and Fisheries. E15 Expert Group on Oceans, Fisheries and Trade System - Policy Options Paper, REF 181215. Available at: <http://www3.weforum.
org/docs/E15/WEF_Fisheries_report_2015_1401. pdf $>$. Accessed on: 16 Dec. 2016.

THORSTENSEN, Vera; FERRAZ, Lucas. A multiplicação dos acordos preferenciais de comércio e o isolamento do Brasil. São Paulo: Instituto de Estudos para o Desenvolvimento Industrial, 2013. Available at: < http://retaguarda.iedi.org.br/midias/artigos/51d18e9168afa9d0. pdf $>$. Accessed on: 20 Dec. 2016.

THORSTENSEN, Vera; NOGUEIRA, Thiago; ARIMA JÚNIOR, Mauro. Introdução. In: THORSTENSEN, Vera; NOGUEIRA (Coord.). O Tratado da Parceria Transpacífica (TPP): Impactos do Novo Marco Regulatório para o Brasil. São Paulo: VT, 2017.

TORPY, Renee. If Criminal Offenses Were Added to CITES, Would Nations be Better Able to Restrict International Trade in Endangered Species and Protect Biodiversity? Revista Brasileira de Direito Internacional, Brasília, v. 9, n. 3, p. 57-70, Dec. 2012.

TRUJILLO, Elizabeth. A Dialogical Approach to Trade and Environment. Journal of International Economic Law, Oxford, v. 16, n. 3, p. 535-585, Mar. 2013.

UNITED NATIONS INSTITUTE FOR TRAINING AND RESEARCH. Annemasse Declaration. Available at: <http://www.un-ppp.org/annemasse-declaration>. Accessed on: 5 Nov. 2016.

UNITED STATES NATIONAL OCEANIC AND ATMOSPHERIC ADMINISTRATION. Implementation of Title IV of the Management Reauthorization Act of 2006. Available at: <http://www.nmfs.noaa.gov/ia/iuu/ msra_page/2009_report.pdf $>$. Accessed on: 5 Dec. 2016.

UNITED STATES TRADE REPRESENTATIVE USTR. Transatlantic Trade and Investment Partnership: TTIP Issue-by-Issue - Environment. Available at: <https:// ustr.gov/trade-agreements/free-trade-agreements / transatlantic-trade-and-investment-partnership-t-tip/ttip-9>. Accessed on: 16 Dec. 2016.

UNITED STATES TRADE REPRESENTATIVE USTR. Trans-Pacific Partnership: leveling the playing field for American workers \& American Businesses. Chapter 20 - Environment (TPP). Available at : < https://medium.com/the-trans-pacific-partnership/environmenta7f25cd180cb\#.8mi33h9nz>. Accessed on: 16 Dec. 2016.

WORLD TRADE ORGANIZATION. Brazil: Mea- 
sures Affecting Imports of Retreaded Tyres. Available at: <https://www.wto.org/english/tratop_e/dispu_e/ cases_e/ds332_e.htm>. Accessed on: 19 Jul. 2017.

WORLD TRADE ORGANIZATION. India etc versus US: Shrimp-Turtle. Available at: <https://www.wto. org/english/tratop_e/envir_e/edis08_e.htm>. Accessed on: 18 Jul. 2017.

WORLD TRADE ORGANIZATION. Mexico etc versus US: Tuna-Dolphin. Available at: <https://www.wto. org/english/tratop_e/envir_e/edis04_e.htm>. Accessed on: 19 Jul. 2017.

WTO SECRETARIAT. 2013 World Trade Report. Available at: <https://www.wto.org/english/res_e/ booksp_e/world_trade_report13_e.pdf $>$. Accessed on: 30 Nov. 2016.
WTO SECRETARIAT. Regional Trade Agreements. Available at: <https://www.wto.org/english/tratop_e/ region_e/region_e.htm>. Accessed on: 15 Nov. 2016.

WTO SECRETARIAT. Trade and Enviroment: DG Azevedo welcomes progress in Environmental Goods Agreement. Available at: <https://www.wto.org/english/news_e/news15_e/envir_14dec15_e.htm>. Accessed on: 16 Dec. 2016.

YOO, Tae; KIM, Inkyoung. Free Trade Agreements for the Environment? Regional economic integration and environmental cooperation in East Asia. International Environmental Agreements: Politics, Law and Economics, v. 15, n. 5, p. 721-738, Oct. 2015. 
Para publicar na Revista de Direito Internacional, acesse o endereço eletrônico www.rdi.uniceub.br ou www.brazilianjournal.org.

Observe as normas de publicação, para facilitar e agilizar o trabalho de edição. 